United States Department of Energy

\title{
LONG-TERM SuRVeILlance PLAN FOR THE FALLS CITY Disposal Site, Falls City, Texas
}

November 1996

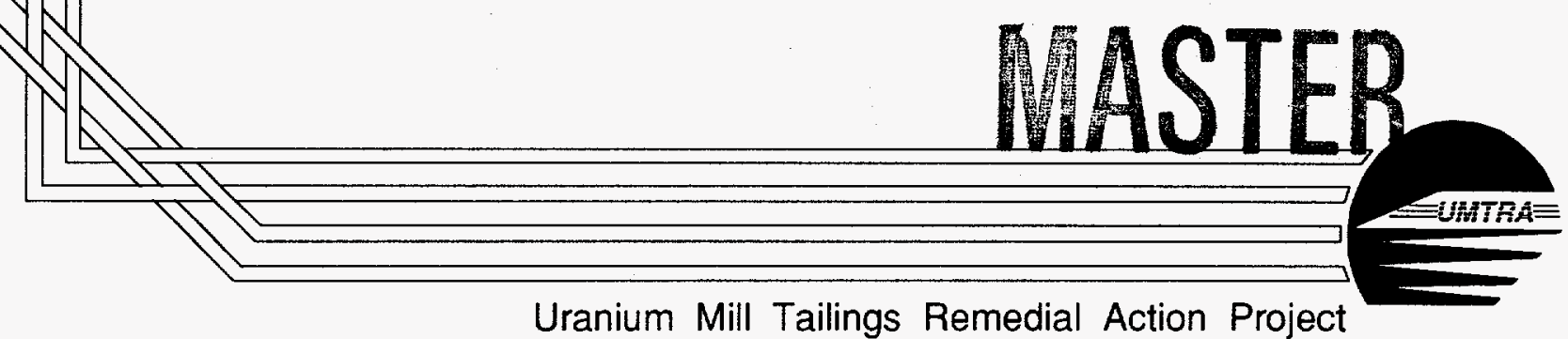

Uranium Mill Tailings Remedial Action Project 
INTENDED FOR PUBLIC RELEASE

This report has been reproduced from the best available copy. Available in paper copy and microfiche.

Number of pages in this report: 120

DOE and DOE contractors can obtain copies of this report from:

Office of Scientific and Technical Information

P.D. Box 62

Oak Ridge, TN 37831

(615) 576-8401

This report is publicly available from:

National Technical Information Service

Department of Commerce

52:85 Port Royal Road

Springfield, VA 22161

(703) 487-4650 
DISCLAMMER

Portions of this document may be illegible in electronic image products. Images are produced from the best available original document. 


\section{DISCLAIMER}

This report was prepared as an account of work sponsored by an agency of the United States Government. Neither the United States Government nor any agency thereof, nor any of their employees, makes any warranty, express or implied, or assumes any legal liability or responsibility for the accuracy, completeness, or usefulness of any information, apparatus, product, or process disclosed, or represents that its use would not infringe privately owned rights. Reference herein to any specific commercial product, process, or service by trade name, trademark, manufacturer, or otherwise does not necessarily constitute or imply its endorsement, recommendation, or favoring by the United States Government or any agency thereof. The views and opinions of authors expressed herein do not necessarily state or reflect those of the United States Government or any agency thereof. 


\section{LONG-TERM SURVEILLANCE PLAN FOR THE FALLS CITY DISPOSAL SITE, FALLS CITY, TEXAS}

November 1996

Prepared for

U.S. Department of Energy

Environmental Restoration Division

UMTRA Project

Albuquerque, New Mexico

Prepared by

Jacobs Engineering Group Inc.

Albuquerque, New Mexico 


\section{TABLE OF CONTENTS}

Section

Page

1.0 INTRODUCTION

1.1 Background

1.2 Licensing process.

$1-2$

1.3 Long-term surveillance plan

2.0 FINAL SITE CONDITIONS

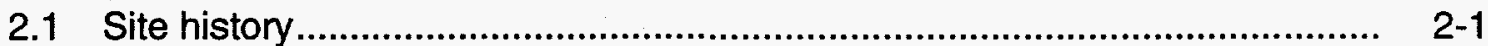

2.2 Description and location of the disposal site area .......................................

2.2.1 Disposal site access and security ................................................. $2-4$

2.2.2 Disposal cell design ....................................................................... $\quad 2-5$

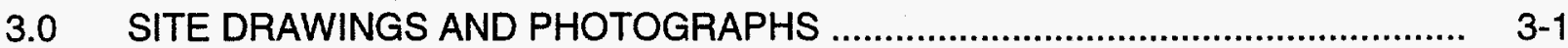

3.1 Disposal site map ...........................................................................

3.2 Disposal site as-built drawings......................................................... $3-2$

3.3 Site baseline photographs .................................................................. $\quad 3-2$

3.4 Site aerial photographs ................................................................... $3-2$

3.5 Site inspection photographs........................................................ $3-2$

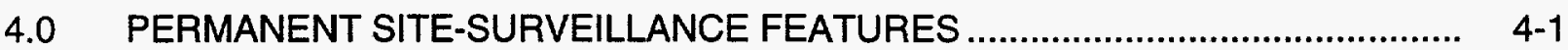

4.1 Survey monuments ......................................................................... $4-1$

4.2 Boundary monuments................................................................... $4-1$

4.3 Site markers ....................................................................................... $4-1$

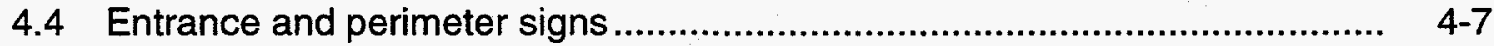

4.5 Settlement plates........................................................................ $4-7$

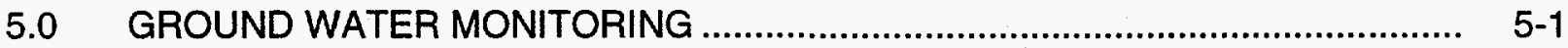

5.1 Ground water characterization ........................................................ $5-1$

5.1.1 Hydrogeologic setting ........................................................... $5-1$

5.1 .2 Background ground water quality............................................... $5-5$

5.2 Ground water monitoring program ...................................................... 5-15

5.2.1 Long-term ground water monitoring ............................................... 5-15

5.2.2 Post-closure ground water monitoring ....................................... 5-15

5.2.3 Monitored Constituents .............................................................. $5-20$

5.3 Data validation and quality assurance .............................................. $5-24$

5.4 Reporting .................................................................................... $5-24$

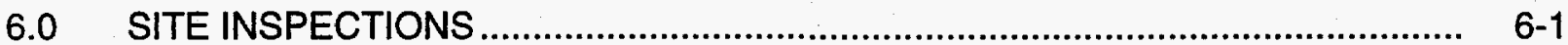

6.1 Inspection frequency ....................................................................... $6-1$

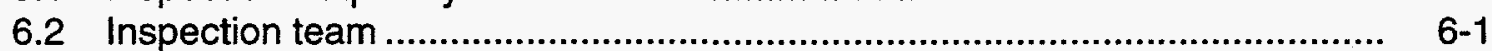

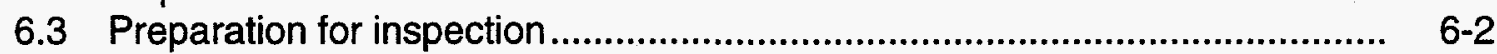


TABLE OF CONTENTS (Continued)

\section{Section}

Page

6.4 Site inspection and inspection checklist ......................................... $6-2$

6.4 .1 Off-site areas .......................................................................... $6-3$

6.4.2 On-site areas ........................................................................... $6-3$

6.5 Modifying processes ................................................................... $6-4$

6.6 Vegetation ......................................................................................... $6-4$

6.6.1 Planned vegetation ................................................................... $6-4$

6.6 .2 Volunteer plant growth ..................................................................... $6-5$

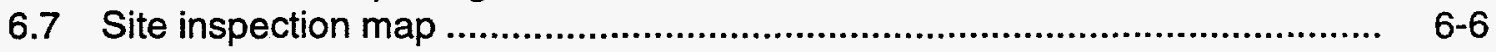

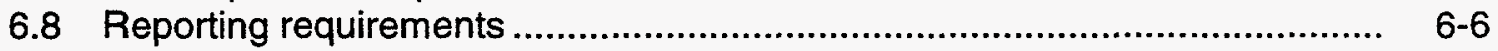

UNSCHEDULED INSPECTIONS ............................................................. $\quad 7-1$

7.1 Follow-up inspections ..................................................................... $7-1$

7.2 Contingency inspections ..................................................................... $7-1$

8.0 CUSTODIAL MAINTENANCE OR REPAIR ................................................. $8-1$

8.1 Planned maintenance ....................................................................... $8-1$

8.2 Unscheduled maintenance or repair ..................................................... $8-1$

8.3 Certification and reporting requirements ........................................ $8-1$

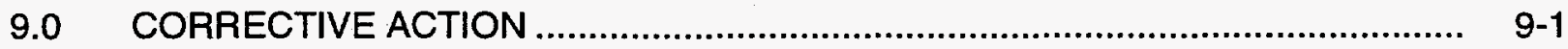

9.1 Problem identification ....................................................................... $9-4$

9.2 Certification and reporting procedures .............................................. $9-4$

10.0 RECORD KEEPING AND REPORTING REQUIREMENTS ............................. 10-1

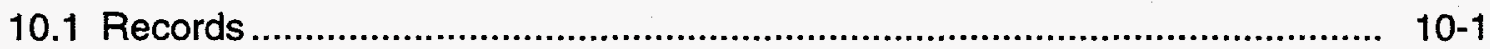

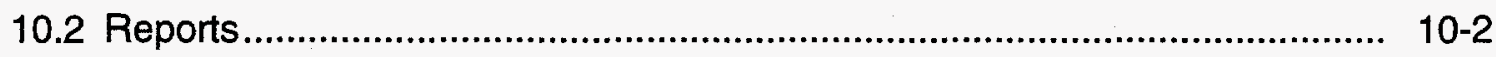

11.0 EMERGENCY NOTIFICATION AND REPORTING..................................... 11-1

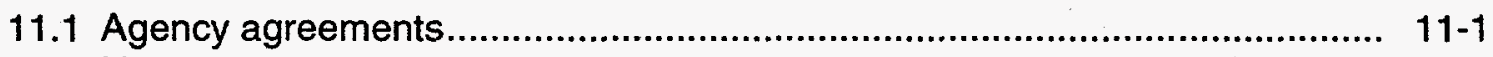

11.2 Unusual occurrences ................................................................ 11-1

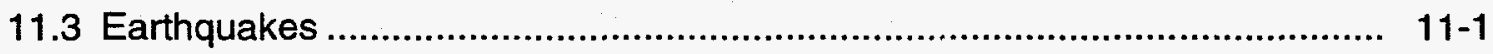

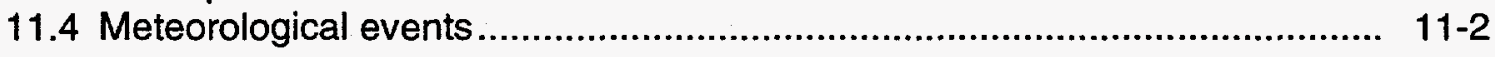

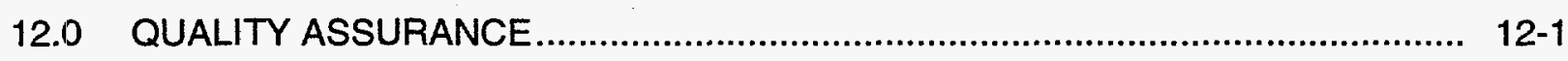

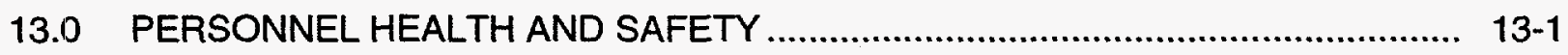

13.1 Health and safety inspections .......................................................... 13-1

13.2 Reportable incidents .................................................................. 13-2

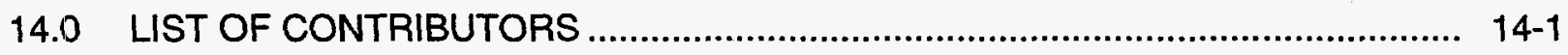




\section{TABLE OF CONTENTS (Concluded)}

Section

Page

15.0 REFERENCES

$15-1$

ATTACHMENT 1

ATTACHMENT 2

ATTACHMENT 3

ATTACHMENT 4

ATTACHMENT 5
SITE OWNERSHIP/CUSTODY DOCUMENTATION

NRC CONCURRENCE AND LICENSING DOCUMENTATION

SITE INSPECTION PHOTO LOG

SITE INSPECTION CHECKLIST

AGENCY NOTIFICATION AGREEMENTS 


\section{LIST OF FIGURES}

Figure

Page

2.1 Area map of tailings piles and ponds, Falls City, Texas, site ............................. $2-2$

2.2 Disposal site location map, Falls City, Texas................................................ $2-3$

4.1 UMTRA Project survey monument, Falls City, Texas, site................................. 4-2

4.2 UMTRA Project boundary monument, Falls City, Texas, site ............................ 4-3

4.3 UMTRA Project site marker at entrance of disposal site, Falls City,

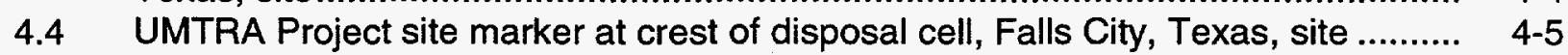

4.5 UMTRA Project site marker incised message, Falls City, Texas, site ................. 4-6

4.6 UMTRA Project entrance sign and message, Falls City, Texas, site ................... 4-8

4.7 UMTRA Project perimeter sign and message, Falls City, Texas, site ................... 4-9

4.8 UMTRA Project settlement plates, Falls City, Texas, site ................................. 4-10

5.1 Surface geology and cross section location, Falls City, Texas, site .................... 5-2

5.2 Cross section (A-A') of uppermost aquifer, Falls City, Texas, site ....................... $5-4$

5.3 Locations of monitor wells, former tailings piles, and disposal cell,
Falls City, Texas, site ................................................................................

5.4 Locations of the Dilworth background wells and the Deweesville/
Conquista Conoco 600 series wells, Falls City, Texas, site ...............................

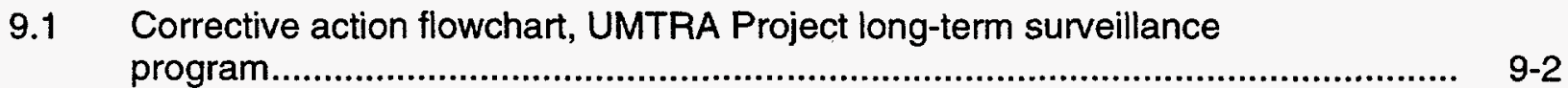

9.2 Key elements in the corrective action process............................................ $9-3$

\section{LIST OF PLATES}

PLATE 1 FINAL DISPOSAL SITE SURVEY MAP

PLATE 2 FALLS CITY DISPOSAL SITE MAP 


\section{LIST OF TABLES}

Table

Page

2.1 Falls City disposal site key holders

3.1 Aerial photography specifications for the Falls City, Texas, disposal site

5.1 Typical water quality data for Dilworth and Deweesville/Conquista background wells.

5.2 Water quality in the Deweesville/Conquista aquifer at the Falls City, Texas, site.

5.3 Statistical summary of the Dilworth background ground water quality data at the Falls City, Texas, site

5.4 Ground water monitoring network, Falls City, Texas, site.

5.5 Filtered water quality of tailings fluids at the Falls City, Texas, site.

5.6 Monitored constituents for establishing baseline conditions at the Falls City, Texas, disposal site 


\section{LIST OF ACRONYMS}

\begin{tabular}{ll} 
Acronym & \multicolumn{1}{c}{ Definition } \\
bls & below land surface \\
DDE & U.S. Department of Energy \\
DQO & data quality objective \\
EA & environmental assessment \\
EFA & U.S. Environmental Protection Agency \\
FM & farm-to-market road \\
FOD & frequency of detection \\
GJPO & Grand Junction Projects Office \\
LTSP & long-term surveillance plan \\
MCL & maximum concentration limit \\
MSL & mean sea level \\
NRC & U.S. Nuclear Regulatory Commission \\
QA & quality assurance \\
OC & quality control \\
Ra-226 & radium-226 \\
RAC & Remedial Action Contractor \\
RAP & remedial action plan \\
SOP & standard operating procedure \\
SOW & statement of work \\
TAC & Technical Assistance Contractor \\
UMTRA & Uranium Mill Tailings Remedial Action \\
UMTRCA & Uranium Mill Tailings Radiation Control Act \\
UPDCC & UMTRA Project Document Control Center \\
USGS & U.S. Geological Survey \\
\end{tabular}




\subsection{GROUND WATER MONITORING}

The need for ground water monitoring at the Falls City disposal site was evaluated in accordance with the NRC regulations in 10 CFR $\$ 40.27(b)(2)(1995)$, and guidelines established by the DOE in Guidance for Implementing the Long-term Surveillance Program for UMTRA Project Title I Disposal Sites (DOE, 1996). Based on evaluation of site characterization data, it has been determined that a program to monitor ground water for demonstration of disposal cell performance based on a set of concentration limits is not appropriate because ground water in the uppermost aquifer is of limited use, and a narrative supplemental standard has been applied to the site that does not include numerical concentration limits or a point of compliance (POC) (40 CFR \$192.21(g) [1995]). The limited use designation is based on the fact that ground water in the uppermost aquifer is not currently or potentially a source of drinking water in the area because it contains widespread ambient contamination that cannot be cleaned up using methods reasonably employed by public water supply systems. Background ground water quality varies by orders of magnitude since the aquifer is in an area of redistribution of uranium mineralization derived from ore bodies.

The DOE plans to perform post-closure ground water monitoring in the uppermost aquifer as a "best management practice" (BMP) as requested by the state of Texas. The purpose of the BMP monitoring is to provide additional background and characterization information, and to evaluate trends in ground water quality (naturally-occurring or site-related). Ground water sampling will be conducted semiannually for up to five years following completion of the disposal cell (until 1999). Upon completion of the sampling program, ground water conditions will be assessed based on the additional information collected, and the BMP monitoring will be discontinued. The NRC will participate in the assessment process.

BMP monitoring is not required under the regulations for the purpose of demonstrating compliance with the final EPA ground water protection standards (40 CFR \$192.02 [1995]) and will not trigger corrective action (40 CFR \$192.04 [1995]).

\subsection{GROUND WATER CHARACTERIZATION}

The DOE's characterization of the hydrogeologic units, aquifer hydraulic and transport properties, tailings materials, and geochemical conditions at the Falls City disposal site (presented in detail in the Falls City RAP [DOE, 1992b]) is summarized below.

\subsubsection{Hydrogeologic setting}

The Falls City site is underlain by clastic sedimentary strata that dip gently southeast (approximately $20 \mathrm{ft}$ per $1000 \mathrm{ft}$ [slope $=0.02]$ ) as part of the thick homoclinal sequence of the Gulf Coastal Plain. The local sedimentary strata are comprised of generally unlithified sand, silt, and clay deposits of the Whitsett and Manning Clay Formations. The site overlies outcrops of the Dubose Clay, Deweesville Sandstone, and Conquista Clay Members of the Whitsett Formation (Figure 5.1).

Three low-yield water-bearing strata are within the upper $200 \mathrm{ft}(60 \mathrm{~m})$ of the Whitsett Formation sediments underlying the site: 1) the Deweesville Sandstone Member; 2) 


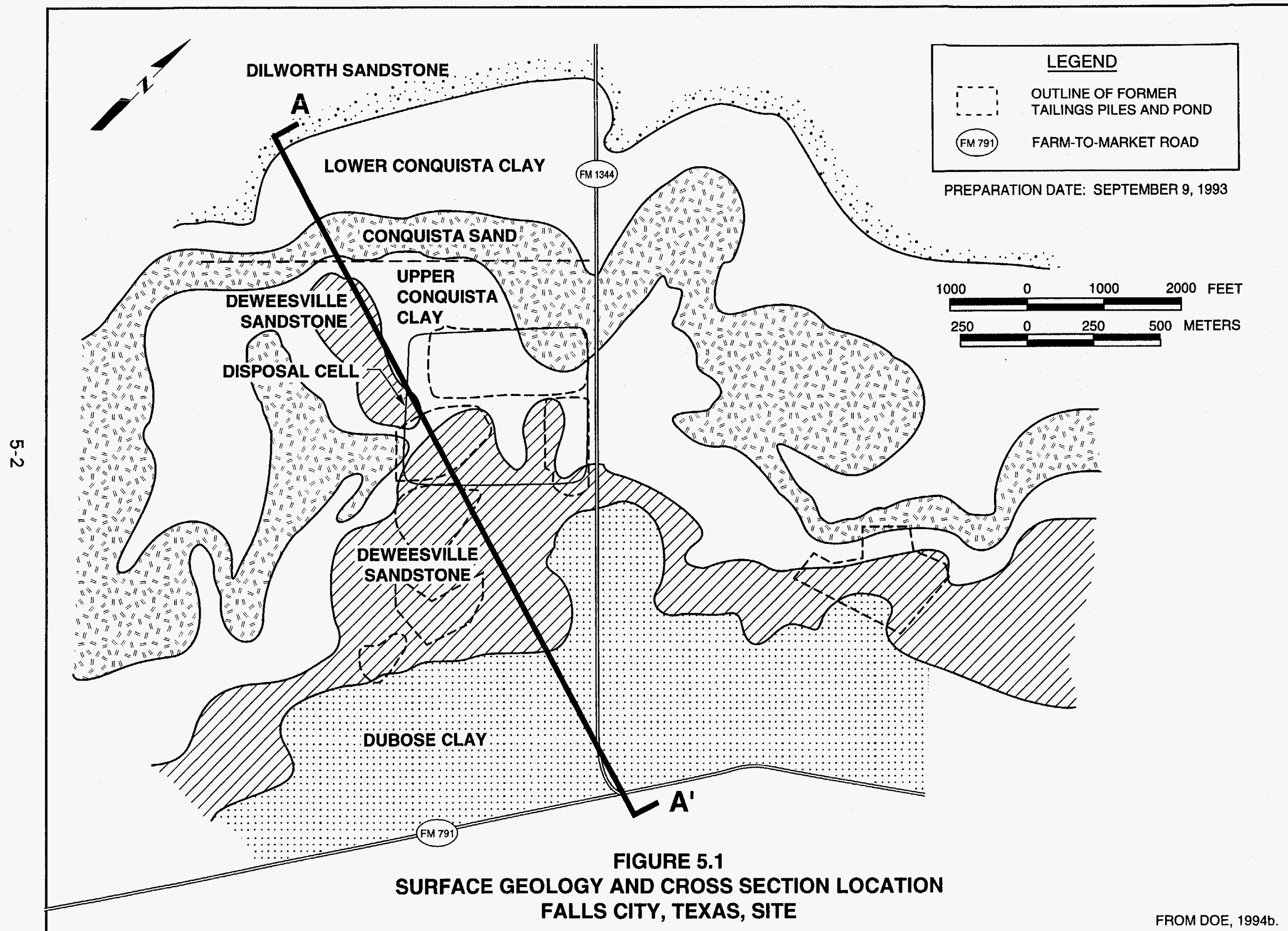


the Conquista Clay Member; and 3) the Dilworth Sandstone Member. The Conquista Clay Member is composed of three subunits: an oxidized upper Conquista Clay/silt, the Conquista Sandstone, and a lower Conquista Clay (Figure 5.2). The Conquista Sandstone extends downdip into the subsurface, but thins significantly and becomes considerably finer grained. The Deweesville Sandstone Member, upper Conquista Clay, and Conquista Sandstone subunits are grouped together as one aquifer, referred to as the Deweesville/Conquista aquifer, because impermeable strata do not separate the members.

\section{Deweesville/Conquista aquifer}

Shallow ground water in the site vicinity is found in the Deweesville/Conquista aquifer at depths of 5 to $30 \mathrm{ft}(2$ to $9 \mathrm{~m}$ ) below land surface (bls). Ground water within the aquifer occurs under unconfined conditions in the northern and western portions of the site vicinity and along creek beds. In areas where the Deweesville/Conquista aquifer is unconfined, the potentiometric surface generally is a subdued replica of the surface topography.

The top of the lower Conquista Clay defines the lower boundary of the Deweesville/Conquista aquifer. The intersection of the Deweesville/Conquista water table and the top of the lower Conquista Clay marks the updip limit of saturation in the Deweesville/Conquista aquifer (Figure 5.2). Two wells were completed updip of this intersection, and consequently, are dry. Because the tailings piles overlaid outcrops of the Deweesville Sandstone and the upper Conquista Clay at the surface, it is impossible to install upgradient, background monitor wells screened in the Deweesville/Conquista aquifer.

The limited use ground water within the Deweesville/Conquista aquifer is recharged by infiltrating precipitation in the Deweesville/Conquista outcrop areas, interformation leakage in downdip areas and, quite possibly, seepage of tailings pore fluids from the disposal cell. Although it is hydrologically feasible for ground water within the Deweesville/Conquista aquifer, immediately downgradient of the disposal cell, to discharge into the eastern or western tributaries of Tordilla Creek, especially during periods of extreme precipitation, there was no evidence of such a phenomena occurring in these areas during site remediation. It is equally plausible for ground water in this aquifer, especially in the southern portion of the formation to flow into the deeper subsurface beneath Farm and Market road 791 and in the western portion into the sandy alluvium and upper Conquista shale subcrop beneath Tordilla Creek, down the creek as underflow, and into the Conquista sandstone subcrop beneath the alluvium. North of former tailings pile 3, ground water flows locally to the north toward Scared Dog Creek.

The horizontal hydraulic conductivities in the Deweesville and Conquista units are highly variable, with a value range of two orders of magnitude. The maximum horizontal hydraulic conductivity for the Deweesville/Conquista aquifer is $2.6 \mathrm{ft} /$ day $\left(9.2 \times 10^{-4} \mathrm{~cm} / \mathrm{s}\right)$ and is calculated from aquifer test data from a well screened in the Conquista Sandstone (DOE, 1992b). Using Darcy's Law, an assumed effective porosity of 0.1 , and an average hydraulic gradient of 0.013 to the east-southeast, the maximum average linear ground water velocity is $130 \mathrm{ft}(40 \mathrm{~m})$ per year. 


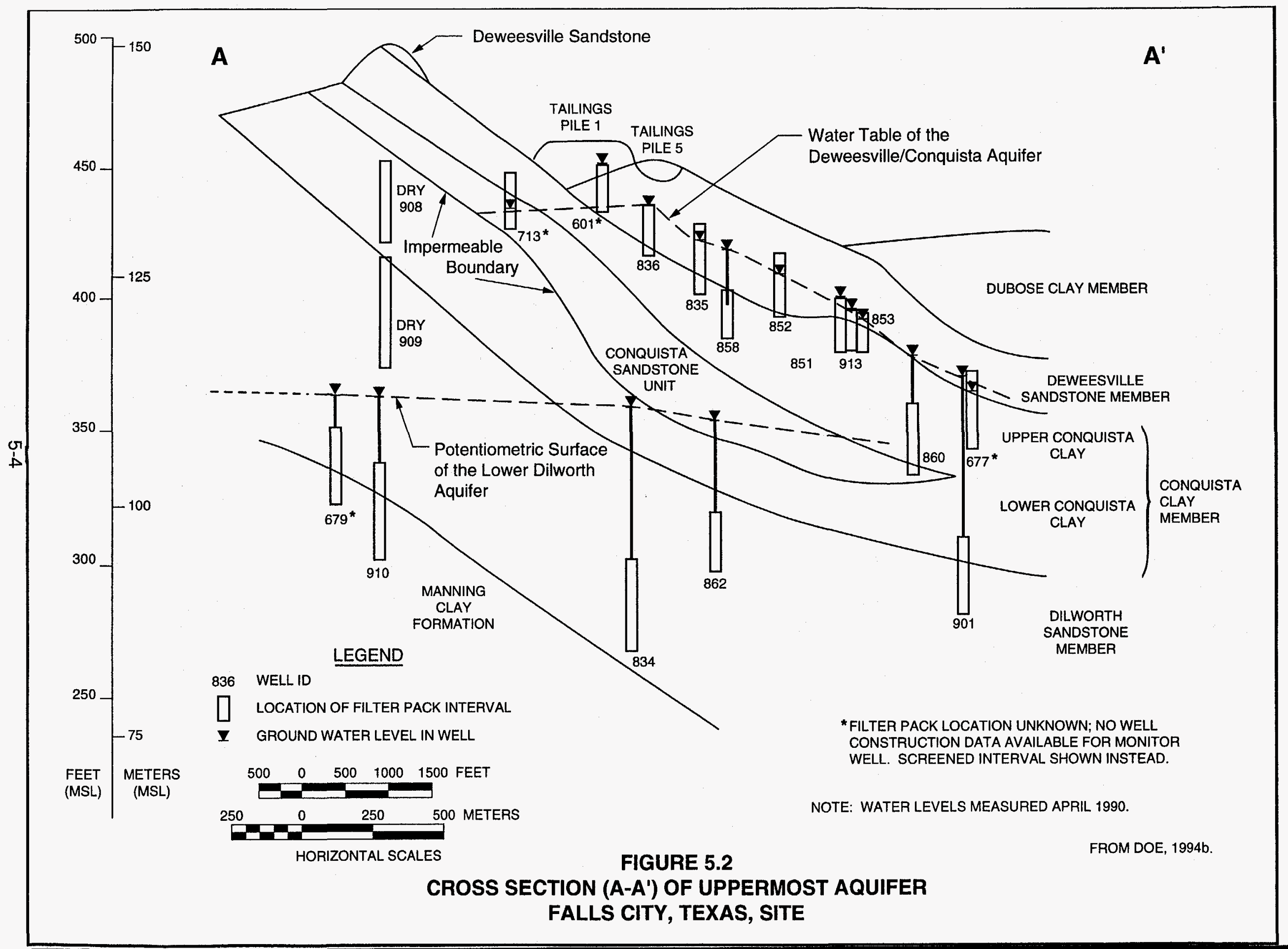




\section{Dilworth aquifer}

The Dilworth aquifer is a sandstone member of the Whitsett Formation. It is separated from the Deweesville/Conquista aquifer by 30 to $50 \mathrm{ft}(9$ to $15 \mathrm{~m})$ of carbonaceous clay of the lower Conquista Clay subunit, which acts as an aquitard to downward seepage. The Dilworth aquifer is approximately $100 \mathrm{ft}(30 \mathrm{~m})$ thick below the disposal cell.

Near the outcrop of the Dilworth sandstone (Figure 5.1), ground water is unconfined. Depths to ground water in the Dilworth aquifer range from approximately 30 to 100 $\mathrm{ft}(9$ to $30 \mathrm{~m})$ bls. Downdip to the southeast, ground water in the Dilworth aquifer becomes confined by the lower Conquista clay. A cross-sectional view of the potentiometric surface of the Dilworth aquifer is shown in Figure 5.2.

Because there is a potential hydraulic interconnection between the Deweesville/Conquista aquifer and the Dilworth unit by improperly abandoned exploratory boreholes, the Dilworth unit is included as part of the uppermost aquifer.

Average linear ground water velocities in the Dilworth aquifer were calculated using a hydraulic conductivity of $0.68 \mathrm{ft}$ day $\left(2.4 \times 10^{-4} \mathrm{~cm} / \mathrm{s}\right.$ ) (approximate maximum value from aquifer tests), a hydraulic gradient of 0.009 to the east-southeast, and an assumed effective porosity of 0.1 for the fine sands of this zone (DOE, 1992b). The average linear velocity for ground water flow in the lower Dilworth aquifer is approximately $22 \mathrm{ft}(6.7 \mathrm{~m})$ per year.

\subsubsection{Background ground water quality}

Background ground water quality for the Deweesville/Conquista and Dilworth aquifers is defined as the quality of ground water at the Falls City site that would be present if uranium processing activities had not occurred.

There is no single background ground water quality for each of these aquifers. The natural ground water quality varies within these aquifers as a function of residence time and aquifer matrix composition. The Deweesville/Conquista and Dilworth aquifers can each be separated into three general regions or zones with different mineralogical and compositional characteristics. These zones are defined as the oxidized, transitional, and reduced zones. Although these zones overlap, the ground water in each zone typically is distinct in composition from the ground water in the other zones. This is especially true of metals. For example, iron and manganese occur at greater concentrations in the reduced zones, while uranium occurs at greater concentrations in the oxidized zone. Table 5.1 summarizes the range of background ground water quality in each of these zones at the site. The composition of typical tailings pore fluid is provided for comparison.

Other water quality data are presented in the Falls City RAP (DOE, 1992b). The numerous unmined and mined ore bodies in the oxidized, transitional, and reduced zones of the regional sediments and variations in geochemical conditions cause considerable variation in the natural concentrations of hazardous trace constituents including uranium (Table 5.1). 


\begin{tabular}{|c|c|c|c|c|c|c|c|c|c|}
\hline \multirow{2}{*}{ 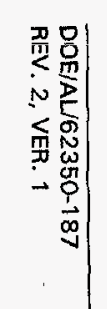 } & \multirow[b]{2}{*}{ Constituents } & \multirow{2}{*}{$\frac{\begin{array}{c}\text { Tailings } \\
\text { fluid }^{\mathrm{a}}\end{array}}{607}$} & \multicolumn{2}{|c|}{ Reduced zone } & \multicolumn{2}{|c|}{ Transitional zone } & \multicolumn{3}{|c|}{ Oxidized zone (outcrop area) } \\
\hline & & & 667 & 668 & 951 & 969 & 967 & 968 & 979 \\
\hline \multirow{14}{*}{ ç } & Alkalinity ${ }^{b}$ & NA & 252 & 250 & 307 & 291 & 116 & 226 & 193 \\
\hline & Calcium & 494 & 335 & 405 & 364 & 495 & 278 & 90 & 258 \\
\hline & Chloride & 1210 & 785 & 944 & 708 & 779 & 793 & 338 & 672 \\
\hline & Iron & 430 & 0.45 & 0.19 & 0.03 & 0.87 & $<0.03$ & $<0.03$ & $<0.03$ \\
\hline & Magnesium & 185 & 31.8 & 45.1 & 29 & 61 & 30.5 & 8.1 & 28.3 \\
\hline & Manganese & 21.8 & 0.21 & 0.78 & 0.21 & 2.94 & 0.02 & $<0.01$ & 0.07 \\
\hline & Nitrate & 0.5 & 4.9 & 3.5 & 4 & 1.3 & 10.2 & 12.4 & 4.4 \\
\hline & $\mathrm{pH}$ & 2.95 & 6.65 & 6.63 & 6.75 & 6.70 & 5.98 & 6.58 & 6.08 \\
\hline & Potassium & 1.77 & 43 & 29 & 45 & 43 & 30 & 18 & 36 \\
\hline & Sodium & 739 & 678 & 583 & 652 & 550 & 675 & 121 & 531 \\
\hline & Sulfate & 7700 & 1043 & 930 & 856 & 1290 & 817 & 156 & 569 \\
\hline & Total dissolved solids & 12900 & 3120 & 3310 & 2291 & 3650 & 2750 & 624 & 2210 \\
\hline & Uranium & 1.19 & 0.015 & 0.017 & 0.008 & 0.010 & 0.003 & 0.068 & 0.25 \\
\hline & $\begin{array}{l}{ }^{a} \text { Water quality data fror } \\
{ }^{b} \mathrm{mg} / \mathrm{L} \mathrm{CaCO}_{3} \text {. } \\
\text { Notes: } \\
\text { 1. Water quality data } \mathrm{f} \\
\text { and Deweesville/Co }\end{array}$ & $\begin{array}{l}\text { January } 1 \\
\text { muista back }\end{array}$ & $\begin{array}{l}\text { July } 199 \\
\text { wells } 95\end{array}$ & $\begin{array}{l}\text { om Dilwo } \\
67 \text {, and } 6\end{array}$ & $\begin{array}{l}\text { kground } \\
\text { cept wher }\end{array}$ & $\begin{array}{l}\text { Is } 967,9 \\
\text { oted (Fig }\end{array}$ & $\begin{array}{l}969, \text { and } 9 \\
.3) .\end{array}$ & & \\
\hline 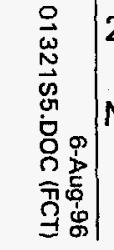 & $\begin{array}{l}\text { 2. Concentrations are } \\
\text { NA - Not analyzed. }\end{array}$ & ported in $m$ & s per lite & $g / L)$ exce & & & & & \\
\hline
\end{tabular}




\section{Deweesville/Conquista}

The oxidized zone of the Deweesville/Conquista aquifer is defined as the outcrop area and shallow subsurface. At the Falls City site, this zone was largely unsaturated before mining and milling. The oxidized zone later became saturated by the influx of large volumes of tailings leachate and mill processing water. Thus, ground water in this zone at the mill site is not the result of natural processes. Therefore, a background ground water quality for the oxidized, outcrop zone of the Deweesville/Conquista aquifer does not exist in the mill site area. The transitional zone begins at the downdip edge of the Deweesville/Conquista outcrop (where the sediments are dominantly oxidized) and ends at about the location of FM-791 (where the sediments are dominantly reduced). Ground water quality before mining and milling activities in the uranium mineralized zone might have been similar to that found in monitor well 951 or monitor well 969 (Table 5.1 and Figure 5.3).

The upgradient limit of the reduced zone for the Deweesville/Conquista outcrop was identified by the DOE and Texas Bureau of Economic Geology as being at the downgradient edge of the DOE monitor well array (beginning at FM-791). Ground water quality data from Conoco monitor wells 667 and 668 suggest the ground water quality of the Deweesville/Conquista in parts of this reduced zone is higher in iron and manganese and perhaps sulfate, chloride, and other constituents than water from the oxidized zone. Figure 5.4 shows the locations of the Conoco monitor wells (667 and 668) and Dilworth background monitor wells.

To expand the background water quality database for the Deweesville/Conquista aquifer, ground water quality data from other areas in the Deweesville/Conquista were evaluated. Thirty-nine monitor wells were completed in the Deweesville Sandstone before mining activities began at the Hobson in situ uranium mine site, about $7 \mathrm{mi}$ (about $11 \mathrm{~km}$ ) east of the Falls City site. Of those 39 wells, 28 were completed in the Deweesville Sandstone ore body and the remaining 11 were completed nearby. Table 5.2 presents a statistical summary of data obtained from the Deweesville monitor wells, including background and site-contaminated ground water quality data. The Deweesville wells at the Hobson site are generally screened between 300 and $450 \mathrm{ft}(90$ to $140 \mathrm{~m}$ ) below surface. Therefore, ground water from the Hobson site has probably migrated farther into the reduced zone of this aquifer than ground water from monitor wells 667 and 668 . There are lower concentrations of sulfate, chloride, and other major and minor constituents in the Hobson ground water relative to the 600 series wells (Table 5.2).

Unlike major and minor element data, the trace element data from the Hobson area ground water differ from those of monitor wells 667 and 668 . By contrast, the Hobson data show significantly elevated levels of lead, radium-226, and uranium (Table 5.2), because most of the Hobson samples were Deweesville ground water that is equilibrating with uranium ore. These data demonstrate the natural variation in Deweesville/Conquista water quality throughout the region due, in part, to the presence or absence of uranium mineralization. 


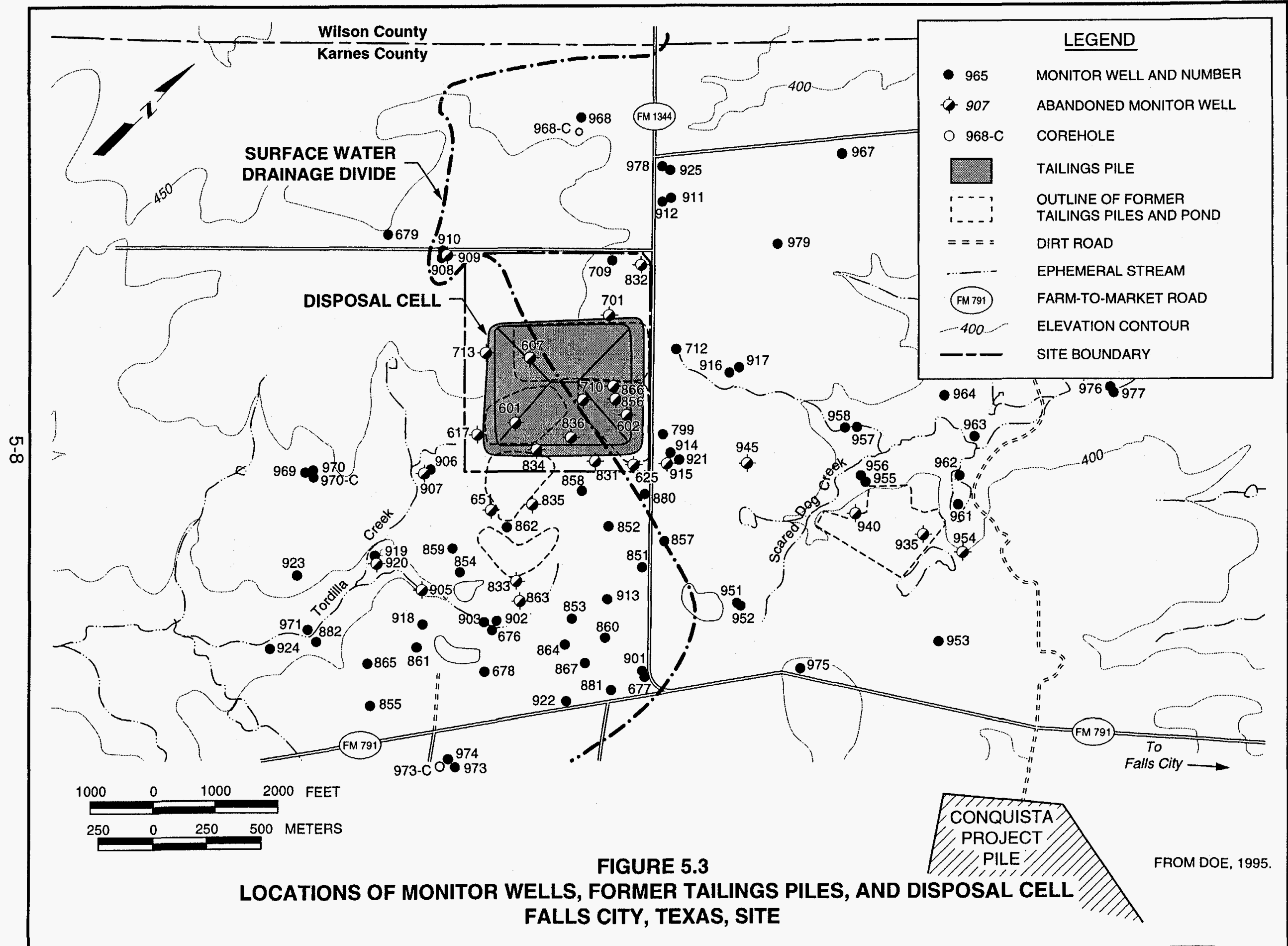




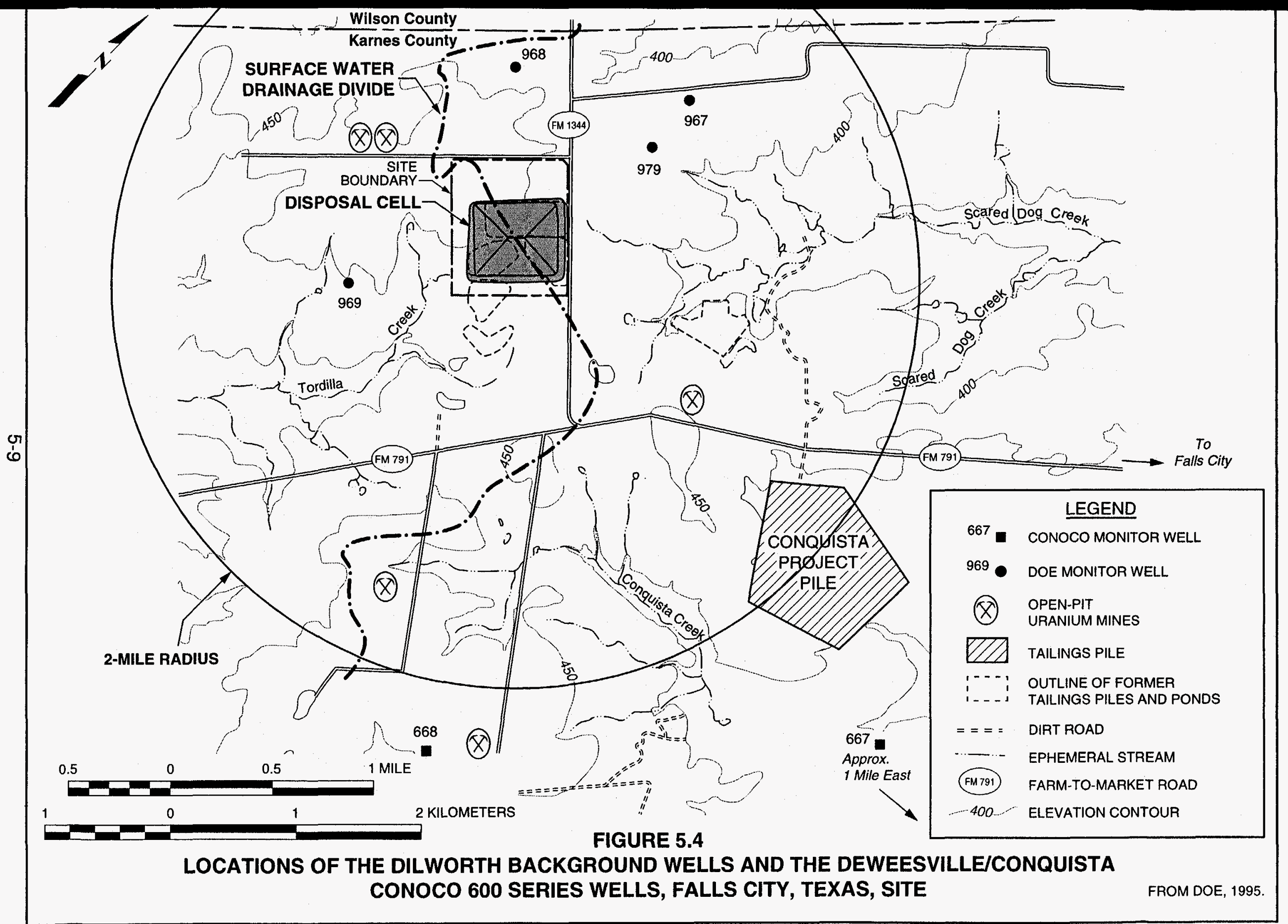




\begin{tabular}{|c|c|c|c|c|c|c|c|c|c|}
\hline \multirow{3}{*}{ 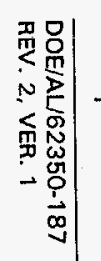 } & \multirow[b]{3}{*}{ Constituent } & \multicolumn{4}{|c|}{ Background ground water } & \multirow{2}{*}{\multicolumn{4}{|c|}{ Contaminated ground water at mill site by region }} \\
\hline & & \multirow{2}{*}{$\begin{array}{l}\text { On-site cross } \\
\text { gradient well } \\
\text { (well 951) }\end{array}$} & \multirow{2}{*}{$\begin{array}{c}\text { Area southeast of } \\
\text { FM } 791^{\circ} \\
\text { (wells } 667 \text { and 668) }\end{array}$} & \multicolumn{2}{|c|}{ Hobson area } & & & & \\
\hline & & & & Mine zone & Production zone & East $^{\mathrm{d}}$ & North $^{\mathrm{e}}$ & South $^{\top}$ & West $^{\mathrm{g}}$ \\
\hline \multirow{19}{*}{$\frac{1}{0}$} & Inorganic & & & & & & & & \\
\hline & Aluminum & & & & & & & & \\
\hline & $\begin{array}{l}\text { FOD } \\
\text { Range }\end{array}$ & $\begin{array}{c}2 / 6 \\
<0.05-0.05\end{array}$ & $\begin{array}{c}0 / 6 \\
<0.05-<0.1\end{array}$ & NA & NA & $\begin{array}{c}27 / 29 \\
<0.05-98\end{array}$ & $\begin{array}{c}9 / 17 \\
<0.05-796\end{array}$ & $\begin{array}{c}17 / 35 \\
<0.05-109\end{array}$ & $\begin{array}{c}22 / 31 \\
<0.05-57\end{array}$ \\
\hline & Ammonium & & & & & & & & \\
\hline & $\begin{array}{l}\text { FOD } \\
\text { Range }\end{array}$ & $\begin{array}{c}5 / 6 \\
<0.1-0.8\end{array}$ & $\begin{array}{c}2 / 6 \\
<0.1-0.3\end{array}$ & NA & NA & $\begin{array}{c}25 / 28 \\
<0.01-3.9\end{array}$ & $\begin{array}{c}13 / 16 \\
0.05-268\end{array}$ & $\begin{array}{c}31 / 31 \\
0.1-2.1\end{array}$ & $\begin{array}{c}23 / 30 \\
<0.01-1.2\end{array}$ \\
\hline & Antimony & & & & & & & & \\
\hline & $\begin{array}{l}\text { FOD } \\
\text { Range }\end{array}$ & $\begin{array}{c}1 / 7 \\
<0.003-0.014\end{array}$ & $\begin{array}{c}0 / 6 \\
<0.003\end{array}$ & NA & NA & $\begin{array}{c}7 / 33 \\
<0.003-0.031\end{array}$ & $\begin{array}{c}4 / 18 \\
<0.003-0.007\end{array}$ & $\begin{array}{c}5 / 33 \\
<0.003-0.029\end{array}$ & $\begin{array}{c}4 / 30 \\
<0.003-0.013\end{array}$ \\
\hline & Arsenic & & & & & & & & \\
\hline & $\begin{array}{l}\text { FOD } \\
\text { Range }\end{array}$ & $\begin{array}{c}4 / 7 \\
0.008-0.01\end{array}$ & $\begin{array}{c}6 / 6 \\
0.01-0.02\end{array}$ & $\stackrel{?}{0.003-0.035}$ & $\stackrel{?}{0.003-0.09}$ & $\begin{array}{c}9 / 33 \\
0.001-0.09\end{array}$ & $\begin{array}{c}9 / 19 \\
0.005-0.16\end{array}$ & $\begin{array}{c}16 / 37 \\
0.001-0.30\end{array}$ & $\begin{array}{c}8 / 34 \\
0.001-0.02\end{array}$ \\
\hline & Barium & & & & & & & & \\
\hline & $\begin{array}{l}\text { FOD } \\
\text { Range }\end{array}$ & $\begin{array}{c}6 / 7 \\
0.02-0.04\end{array}$ & $\begin{array}{c}2 / 6 \\
0.03-0.06\end{array}$ & $\begin{array}{c}? \\
<0.4\end{array}$ & $\begin{array}{l}? \\
<0.4\end{array}$ & $\begin{array}{c}22 / 33 \\
<0.01-0.06\end{array}$ & $\begin{array}{c}15 / 19 \\
<0.01-0.04\end{array}$ & $\begin{array}{c}32 / 37 \\
0.01-0.08\end{array}$ & $\begin{array}{c}23 / 34 \\
<0.01-0.11\end{array}$ \\
\hline & Beryllium & & & & & & & & \\
\hline & $\begin{array}{l}\text { FOD } \\
\text { Range }\end{array}$ & $\begin{array}{c}0 / 7 \\
<0.005-<0.01\end{array}$ & $\begin{array}{c}0 / 6 \\
<0.005-<0.01\end{array}$ & NA & NA & $\begin{array}{c}24 / 33 \\
<0.005-0.62\end{array}$ & $\begin{array}{c}6 / 18 \\
<0.005-0.38\end{array}$ & $\begin{array}{c}13 / 33 \\
<0.005-0.20\end{array}$ & $\begin{array}{c}16 / 30 \\
<0.005-0.09\end{array}$ \\
\hline & Boron & & & & & & & & \\
\hline & $\begin{array}{l}\text { FOD } \\
\text { Range }\end{array}$ & $\begin{array}{c}6 / 6 \\
0.7-1.0\end{array}$ & $\begin{array}{c}6 / 6 \\
0.5-1.0\end{array}$ & $0.06-2.3$ & $0.8-3.0$ & $\begin{array}{c}29 / 29 \\
0.5-2.4\end{array}$ & $\begin{array}{c}16 / 16 \\
0.5-1.8\end{array}$ & $\begin{array}{c}31 / 31 \\
0.9-2.4\end{array}$ & $\begin{array}{c}27 / 27 \\
0.7-2.2\end{array}$ \\
\hline & Bromide & & & & & & & & \\
\hline & $\begin{array}{l}\text { FOD } \\
\text { Range }\end{array}$ & $\begin{array}{c}6 / 6 \\
1.0-4\end{array}$ & $\begin{array}{c}6 / 6 \\
2.5-4.8\end{array}$ & NA & NA & $\begin{array}{l}27 / 27 \\
0.6-12\end{array}$ & $\begin{array}{l}14 / 16 \\
0.7-19\end{array}$ & $\begin{array}{l}27 / 30 \\
0.8-28\end{array}$ & $\begin{array}{l}25 / 27 \\
0.3-25\end{array}$ \\
\hline & Cadmium & & & & & & & & \\
\hline & $\begin{array}{l}\text { FOD } \\
\text { Range }\end{array}$ & $\begin{array}{c}3 / 7 \\
<0.001-0.009\end{array}$ & $\begin{array}{c}0 / 6 \\
<0.001-<0.01\end{array}$ & $\begin{array}{c}? \\
0.01-0.01\end{array}$ & $\stackrel{?}{0.005-0.01}$ & $\begin{array}{c}27 / 33 \\
<0.00-0.99\end{array}$ & $\begin{array}{c}14 / 19 \\
<0.001-0.55\end{array}$ & $\begin{array}{c}20 / 37 \\
<0.001-0.18\end{array}$ & $\begin{array}{c}22 / 34 \\
<0.001-0.05\end{array}$ \\
\hline \multirow{2}{*}{ 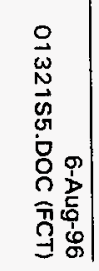 } & Calcium & & & & & & & & \\
\hline & $\begin{array}{l}\text { FOD } \\
\text { Range }\end{array}$ & $\begin{array}{c}7 / 7 \\
297-364\end{array}$ & $\begin{array}{c}6 / 6 \\
321-422\end{array}$ & $\begin{array}{c}? \\
75-180\end{array}$ & $\begin{array}{c}? \\
69-120\end{array}$ & $\begin{array}{c}33 / 33 \\
323-975\end{array}$ & $\begin{array}{c}9 / 19 \\
38-1760\end{array}$ & $\begin{array}{c}37 / 37 \\
396-3710\end{array}$ & $\begin{array}{c}34 / 34 \\
509-1720\end{array}$ \\
\hline
\end{tabular}




\begin{tabular}{|c|c|c|c|c|c|c|c|c|c|}
\hline \multirow{4}{*}{ 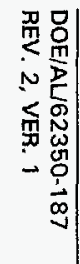 } & \multirow[b]{4}{*}{ Constituent } & Table 5.2 & \multicolumn{7}{|c|}{ Water quality in the Deweesville/Conquista aquifer at the Falls City, Texas, site (Continued) } \\
\hline & & \multicolumn{4}{|c|}{ Background ground water } & \multirow{2}{*}{\multicolumn{4}{|c|}{ Contaminated ground water at mill site by region }} \\
\hline & & \multirow{2}{*}{$\begin{array}{l}\text { On-site cross } \\
\text { gradient well } \\
\text { (well 951) }\end{array}$} & \multirow{2}{*}{$\begin{array}{l}\text { Area southeast of } \\
\text { FM } 791^{\circ} \\
\text { (wells } 667 \text { and 668) }\end{array}$} & \multicolumn{2}{|c|}{ Hobson area ${ }^{a}$} & & & & \\
\hline & & & & Mine zone & Production zone & East $^{\mathrm{a}}$ & North $^{\mathbf{e}}$ & South $^{\mathrm{T}}$ & West $^{\text {g }}$ \\
\hline & Chloride & & & & & & & & \\
\hline \multirow{19}{*}{ د } & $\begin{array}{l}\text { FOD } \\
\text { Range }\end{array}$ & $\begin{array}{c}7 / 7 \\
708-780\end{array}$ & $\begin{array}{c}6 / 6 \\
785-1090\end{array}$ & $\begin{array}{c}? \\
379-600\end{array}$ & $\begin{array}{c}? \\
264-542\end{array}$ & $\begin{array}{c}31 / 31 \\
621-2460\end{array}$ & $\begin{array}{c}19 / 19 \\
558-3800\end{array}$ & $\begin{array}{c}36 / 36 \\
680-7480\end{array}$ & $\begin{array}{c}34 / 34 \\
173-6820\end{array}$ \\
\hline & Chromium & & & & & & & & \\
\hline & $\begin{array}{l}\text { FOD } \\
\text { Range }\end{array}$ & $\begin{array}{c}1 / 7 \\
<0.01-0.01\end{array}$ & $\begin{array}{c}0 / 6 \\
<0.01\end{array}$ & $\begin{array}{c}? \\
<0.01-0.1\end{array}$ & $\begin{array}{c}? \\
<0.01-0.1\end{array}$ & $\begin{array}{c}3 / 33 \\
<0.01-0.01\end{array}$ & $\begin{array}{c}5 / 19 \\
<0.01-0.03\end{array}$ & $\begin{array}{c}3 / 37 \\
<0.01-0.02\end{array}$ & $\begin{array}{c}4 / 34 \\
<0.01-0.03\end{array}$ \\
\hline & Cobalt & & & & & & & & \\
\hline & $\begin{array}{l}\text { FOD } \\
\text { Range }\end{array}$ & $\begin{array}{c}1 / 7 \\
0.01\end{array}$ & $\begin{array}{c}0 / 6 \\
<0.03-<0.05\end{array}$ & NA & NA & $\begin{array}{c}31 / 33 \\
<0.03-1.2\end{array}$ & $\begin{array}{c}6 / 18 \\
0.01-0.7\end{array}$ & $\begin{array}{c}15 / 18 \\
0.01-0.6\end{array}$ & $\begin{array}{c}19 / 30 \\
0.01-0.3\end{array}$ \\
\hline & Copper & & & & & & & & \\
\hline & $\begin{array}{l}\text { FOD } \\
\text { Range }\end{array}$ & $\begin{array}{c}1 / 7 \\
<0.01-0.03\end{array}$ & $\begin{array}{c}0 / 6 \\
<0.01-<0.02\end{array}$ & $\begin{array}{c}? \\
0.01-0.2\end{array}$ & $\stackrel{?}{?}<0.01-0.5$ & $\begin{array}{c}13 / 33 \\
<0.01-0.25\end{array}$ & $\begin{array}{c}9 / 18 \\
<0.01-0.12\end{array}$ & $\begin{array}{c}14 / 33 \\
<0.01-0.07\end{array}$ & $\begin{array}{c}14 / 30 \\
<0.01-0.11\end{array}$ \\
\hline & Cyanide & & & & & & & & \\
\hline & $\begin{array}{l}\text { FOD } \\
\text { Range }\end{array}$ & $\begin{array}{c}0 / 5 \\
<0.01-<0.02\end{array}$ & $\begin{array}{c}0 / 6 \\
<0.01\end{array}$ & NA & NA & $\begin{array}{c}1 / 24 \\
<0.01-0.01\end{array}$ & $\begin{array}{c}1 / 12 \\
<0.01-0.02\end{array}$ & $\begin{array}{c}0 / 18 \\
<0.01-<0.02\end{array}$ & $\begin{array}{c}2 / 19 \\
<0.01-0.02\end{array}$ \\
\hline & Fluoride & & & & & & & & \\
\hline & $\begin{array}{l}\text { FOD } \\
\text { Range }\end{array}$ & $\begin{array}{c}6 / 6 \\
0.2-0.8\end{array}$ & $\begin{array}{c}6 / 6 \\
0.6-0.7\end{array}$ & $\begin{array}{c}? \\
0.1-2\end{array}$ & $\stackrel{?}{0.04-0.4}$ & $\begin{array}{c}26 / 28 \\
<0.1-4.3\end{array}$ & $\begin{array}{c}15 / 16 \\
<0.1-43\end{array}$ & $\begin{array}{c}26 / 30 \\
<0.1-12\end{array}$ & $\begin{array}{c}24 / 27 \\
<0.1-4\end{array}$ \\
\hline & Iron & & & & & & & & \\
\hline & $\begin{array}{l}\text { FOD } \\
\text { Range }\end{array}$ & $\begin{array}{c}4 / 7 \\
0.02-0.06\end{array}$ & $\begin{array}{c}5 / 6 \\
<0.03-0.45\end{array}$ & $\begin{array}{c}? \\
0.06-2.3\end{array}$ & $\begin{array}{c}? \\
0.07-5.8\end{array}$ & $\begin{array}{c}29 / 33 \\
<0.03-126\end{array}$ & $\begin{array}{c}11 / 19 \\
0.02-458\end{array}$ & $\begin{array}{c}33 / 37 \\
0.02-49\end{array}$ & $\begin{array}{c}19 / 34 \\
0.02-77\end{array}$ \\
\hline & Lead & & & & & & & & \\
\hline & $\begin{array}{l}\text { FOD } \\
\text { Range }\end{array}$ & $\begin{array}{c}1 / 7 \\
0.001\end{array}$ & $\begin{array}{c}0 / 6 \\
<0.005-<0.01\end{array}$ & $\begin{array}{c}? \\
0.03-0.10\end{array}$ & $\begin{array}{c}? \\
0.02-0.15\end{array}$ & $\begin{array}{c}9 / 33 \\
0.001-0.04\end{array}$ & $\begin{array}{c}4 / 19 \\
0.001-0.02\end{array}$ & $\begin{array}{c}8 / 37 \\
<0.001-0.03\end{array}$ & $\begin{array}{c}7 / 34 \\
0.001-0.02\end{array}$ \\
\hline & Magnesium & & & & & & & & \\
\hline & FOD & $7 / 7$ & $6 / 6$ & $?$ & $?$ & $33 / 33$ & $19 / 19$ & $37 / 87$ & $34 / 34$ \\
\hline & Range & $26-33$ & $32-51$ & $0.3-9.4$ & $1.8-4.2$ & $36-574$ & 5-1050 & $44-752$ & $81-381$ \\
\hline & Manganese & & & & & & & & \\
\hline \multirow{4}{*}{ 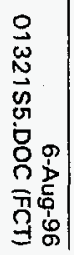 } & $\begin{array}{l}\text { FOD } \\
\text { Range }\end{array}$ & $\begin{array}{c}7 / 7 \\
0.04-0.6\end{array}$ & $\begin{array}{c}6 / 6 \\
0.2-0.8\end{array}$ & $\begin{array}{c}? \\
0.1-0.4\end{array}$ & $\begin{array}{c}? \\
0.03-0.3\end{array}$ & $\begin{array}{c}32 / 33 \\
<0.01-51\end{array}$ & $\begin{array}{c}19 / 19 \\
0.04-74\end{array}$ & $\begin{array}{c}37 / 37 \\
1.59-49\end{array}$ & $\begin{array}{c}34 / 34 \\
0.04-16\end{array}$ \\
\hline & Mercury & & & & & & & & \\
\hline & FOD & $0 / 6$ & $0 / 6$ & $?$ & $?$ & $3 / 29$ & $1 / 15$ & $1 / 30$ & $4 / 28$ \\
\hline & Range & $<0.0002$ & $<0.0002$ & $<0.001-0.001$ & $<0.001$ & $<0.0002-0.002$ & $\begin{array}{c}<0.0002- \\
0.001\end{array}$ & $\begin{array}{c}<0.0002- \\
0.0002\end{array}$ & $\begin{array}{c}<0.0002 \\
0.009\end{array}$ \\
\hline
\end{tabular}




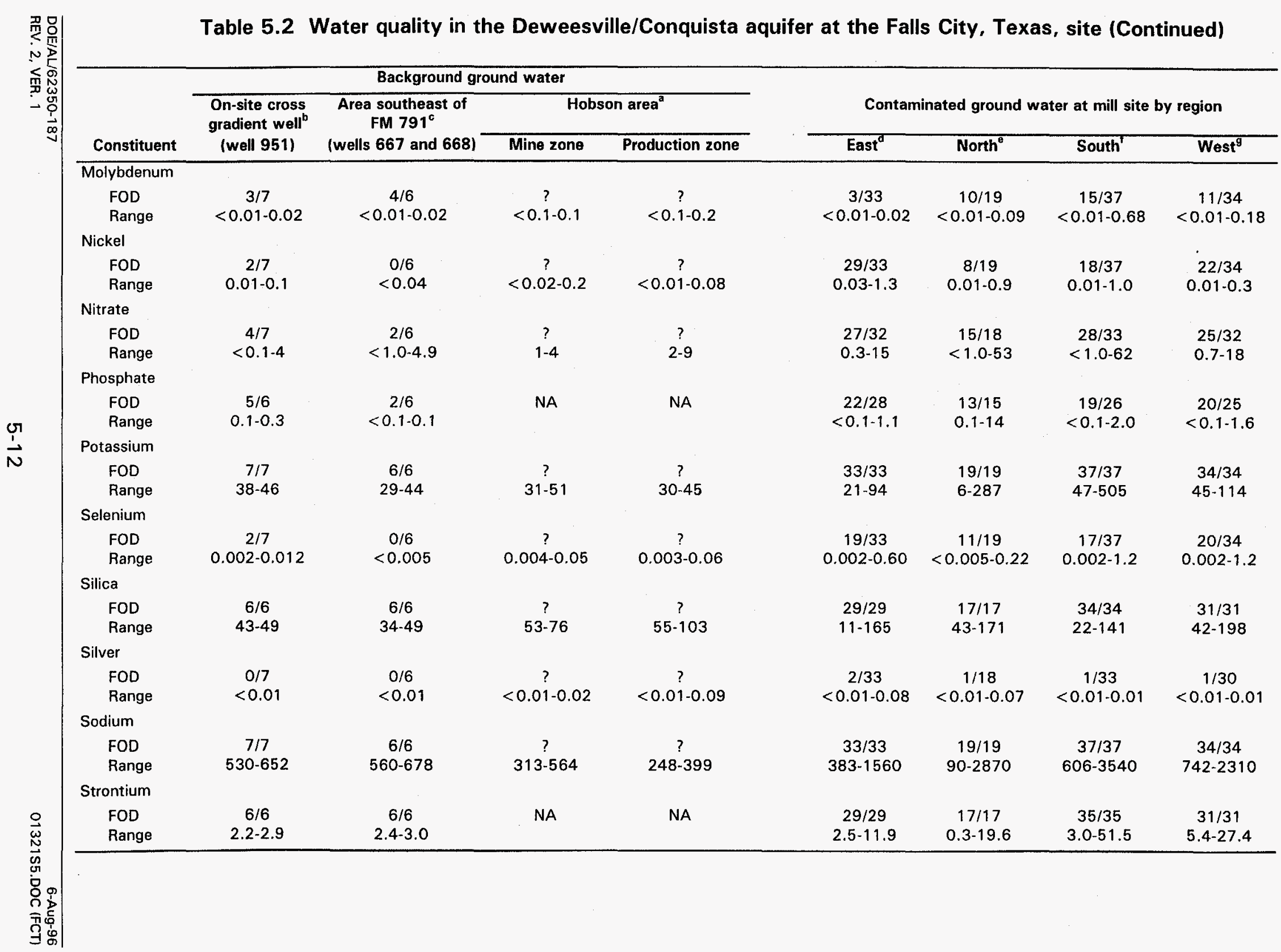




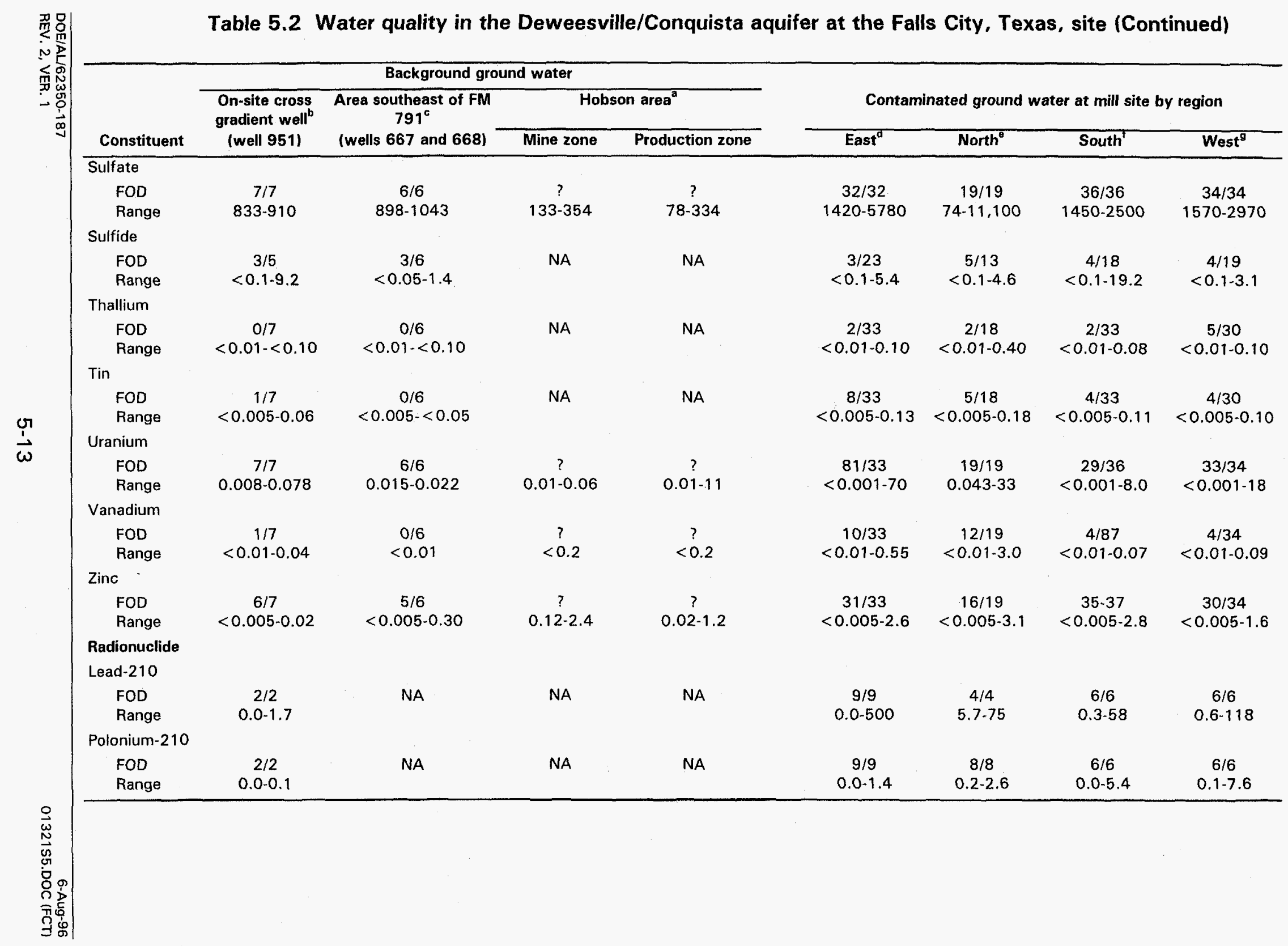


Table 5.2 Water quality in the Deweesville/Conquista aquifer at the Falls City, Texas, site (Concluded)

\begin{tabular}{|c|c|c|c|c|c|c|c|c|}
\hline \multirow[b]{3}{*}{ Constituent } & \multicolumn{4}{|c|}{ Background ground water } & & & & \\
\hline & \multirow{2}{*}{$\begin{array}{l}\text { On-site cross } \\
\text { gradient well } \\
\text { (well 951) }\end{array}$} & \multirow{2}{*}{$\begin{array}{l}\text { Area southeast of FM } \\
791^{c} \\
\text { (wells } 667 \text { and } 668 \text { ) }\end{array}$} & \multicolumn{2}{|c|}{ Hobson area ${ }^{\mathrm{a}}$} & \multicolumn{4}{|c|}{ Contaminated ground water at mill site by region } \\
\hline & & & Mine zone & Production zone & East $^{\text {d }}$ & North $^{6}$ & South' & West $^{9}$ \\
\hline \multicolumn{9}{|l|}{ Radium-226 } \\
\hline $\begin{array}{l}\text { FOD } \\
\text { Range }\end{array}$ & $\begin{array}{c}7 / 7 \\
1.3-2.7\end{array}$ & $\begin{array}{c}6 / 6 \\
1.9-2.8\end{array}$ & $\begin{array}{c}? \\
0.4-15.5\end{array}$ & 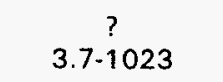 & $\begin{array}{l}33 / 33 \\
0.0-14\end{array}$ & $\begin{array}{l}18 / 18 \\
0.9-34\end{array}$ & $\begin{array}{c}36 / 36 \\
0.4-140\end{array}$ & $\begin{array}{c}34 / 34 \\
0.2-654\end{array}$ \\
\hline \multicolumn{9}{|l|}{ Thorium-230 } \\
\hline $\begin{array}{l}\text { FOD } \\
\text { Range }\end{array}$ & $\begin{array}{c}2 / 2 \\
0.1-0.4\end{array}$ & NA & NA & NA & $\begin{array}{c}9 / 9 \\
0.0-8.1\end{array}$ & $\begin{array}{c}6 / 6 \\
0.0-46\end{array}$ & $\begin{array}{c}11 / 11 \\
0.2-3.6\end{array}$ & $\begin{array}{l}10 / 10 \\
0.0-54\end{array}$ \\
\hline
\end{tabular}

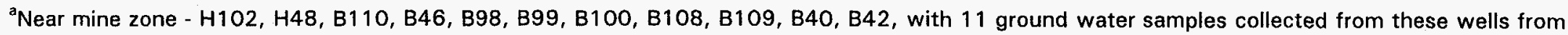
1979 to 1981. Production zone wells - T6-A, M95, M94, M93, T92, M10, M9, M7, M5, M3, T95A, M96, M97, M98, P100, P101, I102, I103, I104, 1105, I106, 1107, M16, M96, M97, M98, H96, H97; 28 ground water samples were collected from these wells from 1978 to 1979.

${ }^{b}$ Monitor well 951 .

${ }^{c}$ Monitor wells 667 and 668 . Filtered-sample data are from 1991.

Wells 940, 953, 955, 963, 965, 966.

eWells $625,713,799,880,914,921$.

fWells $677,853,860,864,867,881,913$.

${ }^{9}$ Wells $854,859,882,904,918,919$.

NA - - data not available (sample was not analyzed for this constituent).

? - - detection limit not reported.

FOD - - frequency of detection; the number of measurements at or above detection limits divided by total number of measurements.

Notes:

1. Filtered samples 1989 to April 1993, except as noted.

2. Concentrations are reported in milligrams per liter, except radionuclides which are reported in picocuries per liter.

Ref: DOE, 1994b. 


\section{Dilworth}

Four upgradient Dilworth monitor wells $(967,968,969$, and 979$)$ were used to delineate the background water quality of this aquifer at the Falls City site. Table 5.3 presents a statistical summary of the water quality of the Dilworth background ground water.

Of the four DOE Dilworth background wells at the Falls City site, three wells (967, 968, and 979) were completed in the oxidized zone, and one well (969) was screened in the transitional zone of the aquifer. Like the Deweesville/ Conquista, ground water quality in the Dilworth is highly variable, including variations in uranium concentrations associated with uranium mineralization (compare data for wells 969 , 967, 968, and 979 in Table 5.1).

\subsection{GROUND WATER MONITORING PROGRAM}

\subsubsection{Long-term ground water monitoring}

Based on evaluation of site characterization data, it has been determined that a program to monitor ground water for demonstration of disposal cell performance based on a set of concentration limits is not appropriate because ground water in the uppermost aquifer is of limited use, and a narrative supplemental standard has been applied to the site that does not include numerical concentration limits or a POC (40 CFR $\$ 192.21(\mathrm{~g})$ [1995]). The limited use designation is based on the fact that ground water in the uppermost aquifer is not a current or potential source of drinking water in the area because it contains widespread ambient contamination (related to mineralization in the area, and associated exploration and mining activities) that cannot be cleaned up using methods reasonably employed by public water supply systems (40 CFR §192.11(e) [1995]). Defining concentration limits and a POC would not provide further protection of human health and the environment.

\subsubsection{Post-closure ground water monitoring}

The DOE plans to perform post-closure ground water monitoring in the uppermost aquifer as a BMP as requested by the state of Texas. The purpose of the BMP monitoring is to provide additional background and characterization information, and to evaluate trends in ground water quality (naturally-occurring or site-related). BMP monitoring is not required under the regulations for the purpose of demonstrating compliance with the final EPA ground water protection standards (40 CFR §192.02 [1995]) and will not trigger corrective action (40 CFR §192.04 [1995]).

BMP monitoring will be performed to further characterize the site, and to evaluate trends in ground water quality, including regional variations in natural background as well as possible impacts from the disposal cell that may be detectable above the naturally elevated levels of constituents in the area. Background ground water quality in the uppermost aquifer is highly variable because of the affect of widespread ambient contamination related to the mineralization in the subsurface, and the associated exploration and mining activities. The anticipated drainage from the disposal cell should be minimal, and concentrations of hazardous constituents 


\begin{tabular}{|c|c|c|c|c|c|c|c|}
\hline \multirow{4}{*}{ 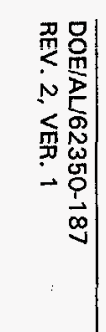 } & statistica & \multirow[b]{4}{*}{$\begin{array}{l}\text { Number of } \\
\text { samples }\end{array}$} & \multirow[b]{4}{*}{$\begin{array}{l}\text { Detection limit(s) } \\
\text { (mg/L) }\end{array}$} & \multirow[b]{4}{*}{$\begin{array}{l}\text { \% above } \\
\text { detection }\end{array}$} & uallty dat & Falls $\mathrm{Ci}$ & Is, site \\
\hline & \multirow[b]{3}{*}{ Constituent } & & & & \multicolumn{3}{|c|}{ Observed concentrations } \\
\hline & & & & & Minimum & Median $^{a}$ & Maximum \\
\hline & & & & & & (mg/L) & \\
\hline \multirow{9}{*}{ 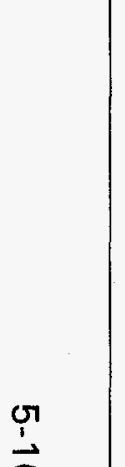 } & Chemical & & & & & & \\
\hline & Aluminum ${ }^{b}$ & 18 & $0.05-0.10$ & 11 & $<0.05$ & NA & 0.05 \\
\hline & Ammonium $^{b}$ & 18 & 0.1 & 67 & $<0.1$ & 0.1 & 2.0 \\
\hline & Antimony & 22 & $0.003-0.02$ & 9 & $<0.003$ & NA & 0.008 \\
\hline & Arsenic (969) & 6 & $0.005-0.010$ & 100 & 0.10 & 0.28 & 0.39 \\
\hline & Barium (969) & 6 & $0.01-0.10$ & 100 & 0.04 & 0.05 & 0.10 \\
\hline & Beryllium $^{b}$ & 22 & $0.005-0.010$ & 0 & NA & NA & NA \\
\hline & Boron (967) & 4 & $0.005-0.10$ & 100 & 0.88 & 1.03 & 1.10 \\
\hline & Bromide (969) & 5 & 0.10 & 100 & 2.6 & 3.2 & 5.8 \\
\hline \multirow[t]{12}{*}{ a } & Cadimium & 22 & 0.001 & 27 & $<0.001$ & NA & 0.005 \\
\hline & Calcium (969) & 6 & $0.01-2.00$ & 100 & 481 & 502 & 560 \\
\hline & Chloride $^{b}(967,969)$ & 11 & 1.0 & 100 & 680 & 793 & 1020 \\
\hline & Chromium & 22 & 0.01 & 18 & $<0.01$ & NA & 0.02 \\
\hline & Cobalt & 22 & $0.01-0.05$ & 14 & 0.01 & NA & 0.05 \\
\hline & Copper & 22 & $0.01-0.02$ & 18 & $<0.01$ & NA & 0.06 \\
\hline & Cyanide & 20 & 0.01 & 10 & $<0.01$ & NA & 0.02 \\
\hline & Fluoride $^{b}$ (979) & 5 & 0.1 & 100 & 0.4 & 0.4 & 0.5 \\
\hline & Iron (969) & 6 & $0.02-0.03$ & 100 & 0.24 & 0.78 & 2.70 \\
\hline & Lead & 22 & $0.001-0.1$ & 9 & 0.001 & NA & 0.002 \\
\hline & Magnesium (969) & 6 & $0.001-0.5$ & 100 & 54 & 57 & 65 \\
\hline & Manganese (969) & 6 & 0.01 & 100 & 2.8 & 3.2 & 3.7 \\
\hline \multirow{2}{*}{ 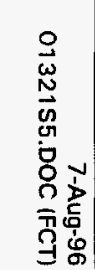 } & Mercury ${ }^{b}$ & 22 & 0.0002 & 0 & NA & NA & NA \\
\hline & Molybdenum $(968,969)$ & 11 & 0.01 & 100 & 0.02 & 0.04 & 0.07 \\
\hline
\end{tabular}




\begin{tabular}{l|l} 
Statistical summary of the Dilworth background ground water quality data at the Falls City, Texas, site \\
(Continued)
\end{tabular}




Statistical summary of the Dilworth background ground water quality data at the Falls City, Texas, site
(Concluded)
Constituent

${ }^{\text {a }}$ The median, or 50 th percentile of the sample data, cannot be determined if 50 percent or less of the data are above detection.

background represents data pooled from monitor wells $967,968,969$, and 979 unless one or more of these wells have significantly higher levels than the others. In such cases, the background represents the higher level.

Filtered samples, 1989-1992

NA - not applicable.

Numbers in parentheses are well numbers.

Ref: DOE, 1994b. 
(quantity and quality) should be low and essentially indistinguishable from the natural quality of ground water in the uppermost aquifer.

Details of the BMP monitoring program are outlined below.

\section{Monitor well network}

The BMP monitoring well network consists of seven existing monitor wells located nearest to the disposal cell (Figure 5.2 and Table 5.4). These monitor wells were selected because they were completed at shallow depths in units immediately underlying the disposal cell, and in units having the greatest hydraulic conductivity at the site. These monitor wells will provide information about trends in ground water levels and ground water quality associated with the aquifer.

Table 5.4 Ground water monitoring network, Falls City, Texas, site

\begin{tabular}{cccc}
\hline & & \multicolumn{2}{c}{$\begin{array}{c}\text { Screened interval } \\
\text { (depth below surface) }\end{array}$} \\
\cline { 3 - 4 } Monitor well number & Member screened & \multicolumn{1}{c}{$(\mathbf{f t})$} & $5-12$ \\
\hline 709 & Conquista Sandstone & $18-38$ & $12-15$ \\
858 & Conquista Sandstone & $40-50$ & $11-14$ \\
880 & Deweesville Sandstone & $35-45$ & $4-09$ \\
906 & Conquista Sandstone & $13-28$ & $12-18$ \\
$908^{\text {a }}$ & Conquista Sandstone & $38-58$ & $4-10$ \\
$916^{\text {a }}$ & Conquista Sandstone & $13-33$ & $14-17$ \\
921 & Conquista Sandstone & $45-55$ & \\
\hline
\end{tabular}

${ }^{a}$ Water level measurement only, unless sufficient water is available for sampling.

Five of the monitor wells are screened in the Deweesville/Conquista aquifer, with four of these wells $1709,858,906$, and 921) in the Conquista Sandstone, and one well $(880)$ in the Deweesville Sandstone. These monitor wells were completed and sampled prior to surface remedial action construction activities, with the exception of the monitor well screened in the Deweesville Sandstone. Ground water quality data from four to twelve sampling rounds are available for these monitor wells.

Two monitor wells (908 and 916) are screened in the unsaturated zone of the Conquista Sandstone. These monitor wells have not historically produced water, but will be monitored to detect potential changes in ground water levels near the disposal cell.

\section{Sampling frequency}

Ground water has been monitored at the Falls City site since 1986. Ground water sampling for the BMP monitoring program will be conducted semiannually for up to five years following completion of the disposal cell (until 1999). Upon completion of 
the sampling program, ground water conditions will be assessed based on the additional information collected. If it is determined that less frequent, or no further monitoring is required, the DOE will modify the LTSP and submit it to NRC for approval.

\subsubsection{Monitored constituents}

\section{Hazardous constituents}

Samples of tailings pore water have been analyzed for hazardous constituents listed in Table 1 to Subpart A and Appendix I to 40 CFR Part 192 (1995). Hazardous constituents were identified from analyses of tailings pore water (DOE, 1992b). The list of these constituents and their levels are provided in Table 5.5.

Inorganic constituents within the tailings at the Falls City site are mostly metals and metalloid elements associated with the uranium ore and milling process. As shown in Table 5.5, median concentrations of arsenic, cadmium, chromium, molybdenum, selenium, uranium, and activities of radium-226 and net gross alpha equal or exceed the maximum concentration limits (MCL) established by the EPA. In addition, nitrate and barium were commonly observed in tailings pore fluids but were typically present at levels below the established MCLs. Lead, mercury, and silver were rarely detected in the tailings pore fluids and, if present, generally occurred at levels below the established MCLs.

Those inorganic hazardous constituents without MCLs which were commonly detected in the tailings pore fluids, are antimony, beryllium, cobalt, copper, nickel, sulfide, thallium, tin, vanadium, and zinc (Table 5.5). Cyanide was rarely detected and, if present, occurred at low levels near the limit of detection. Cyanide is not expected in the tailings because cyanide compounds were not used in uranium processing at the Falls City site.

Tailings pore water was analyzed for Appendix I organic constituents (DOE, 1992b). The organic constituents exceeding laboratory method detection limits are benzene, bromoform, chloroform, dibromochloromethane, ethylbenzene, 2-methylnaphthalene, naphthalene, 1,1,1-trichloroethane, toluene, and xylene. These organic compounds are included as hazardous constituents at the Falls City site (Table 5.6). A more detailed discussion of the organic hazardous constituents is provided in the RAP (DOE, 1992b).

\section{Baseline water quality}

Baseline water quality for the Falls City site is defined as the quality of ground water that has been influenced by uranium processing activities. Baseline conditions have been established, and each monitor well will be analyzed for constituents listed in Table 5.6, including designated inorganic hazardous constituents. In addition to the monitored hazardous constituents, a suite of general water quality indicators (major cations, anions, and standard field measurements) will be monitored and analyzed, with the results being presented to the state. 
Table 5.5 Filtered water quality of tailings fluids at the Falls City, Texas, site

\begin{tabular}{|c|c|c|c|c|c|}
\hline Constituent & $\begin{array}{c}\text { Frequency of } \\
\text { detects }\end{array}$ & Minimum & Median & Maximum & $\mathrm{MCL}$ \\
\hline \multicolumn{6}{|c|}{ EPA inorganics with MCLs } \\
\hline Arsenic & $37 / 58$ & $<0.01$ & 0.12 & 6.5 & 0.05 \\
\hline Barium & $37 / 55$ & $<0.01$ & 0.02 & 0.10 & 1.0 \\
\hline Cadmium & $52 / 58$ & $<0.01$ & 0.17 & 0.58 & 0.01 \\
\hline Chromium & $27 / 55$ & $<0.01$ & 0.05 & 0.50 & 0.05 \\
\hline Lead & $10 / 55$ & $<0.005$ & $<0.03$ & 0.08 & 0.05 \\
\hline Mercury & $5 / 24$ & $<0.0002$ & $<0.0002$ & 0.0009 & 0.002 \\
\hline Molybdenum & $41 / 58$ & $<0.01$ & 0.14 & 11.4 & 0.10 \\
\hline Nitrate & $26 / 40$ & $<0.1$ & 2.1 & 340 & 44 \\
\hline Selenium & $26 / 58$ & $<0.005$ & $<0.05$ & 0.60 & 0.01 \\
\hline Silver & $3 / 54$ & $<0.01$ & $<0.02$ & 0.32 & 0.05 \\
\hline Uranium & $55 / 55$ & 0.044 & 7.57 & 109 & 0.044 \\
\hline Radium-226 & $34 / 34$ & 3.2 & 112 & 906 & 5 \\
\hline Radium-228 & $19 / 19$ & 0.0 & 2.5 & 54.1 & 5 \\
\hline Net -gross alpha & $21 / 40$ & -17309 & 102 & 18996 & 15 \\
\hline
\end{tabular}

\section{EPA MCL organics (only those present above detection limits)}

$\begin{array}{lccccc}\text { Benzene } & 1 / 6 & \text { nd } & \text { nd } & 0.002 & 0.005 \\ \text { Toluene } & 1 / 4 & \text { nd } & \text { nd } & 0.002 & 1.0 \\ \text { Xylene } & 4 / 6 & 0.003 & 0.054 & 0.082 & 10 \\ 1,1,1 \text {-trichloroethane } & 1 / 6 & \text { nd } & \text { nd } & 0.002 & 0.2\end{array}$

\section{Appendix 1 to 40 CFR Part 192 constituents (60 FR 2866)}

\begin{tabular}{lccccc} 
Antimony & $12 / 54$ & $<0.003$ & $<0.05$ & 0.16 & - \\
Beryllium & $49 / 52$ & $<0.005$ & 0.142 & 0.62 & - \\
Bromoform & $1 / 6$ & nd & nd & 0.001 & - \\
Chloroform & $3 / 6$ & 0.013 & 0.025 & 0.082 & - \\
Cobalt & $52 / 55$ & $<0.03$ & 0.60 & 1.70 & - \\
Copper & $43 / 55$ & $<0.01$ & 0.05 & 0.55 & - \\
Cyanide & $2 / 32$ & $<0.01$ & $<0.01$ & 0.06 & - \\
Dibromochloro- & $1 / 6$ & nd & nd & 0.001 & \\
methane & & & & & \\
Napthalene & $4 / 6$ & 0.024 & 0.038 & 0.066 & - \\
Nickel & $51 / 54$ & $<0.04$ & 0.92 & 2.0 & - \\
Sulfide & $7 / 33$ & $<0.1$ & $<0.4$ & 55.3 & - \\
Thallium & $8 / 52$ & $<0.01$ & $<0.1$ & 0.60 & - \\
Tin & $8 / 57$ & $<0.01$ & $<0.1$ & 0.18 & - \\
Vanadium & $48 / 58$ & $<0.01$ & 1.05 & 8.91 & - \\
Zinc & $55 / 55$ & 0.019 & 3.30 & 8.6 & - \\
2-methyl-napthalene & $2 / 6$ & 0.006 & 0.010 & 0.017 & - \\
\hline
\end{tabular}


Table 5.5 Filtered water quality of tailings fluids at the Falls City, Texas, site (Concluded)

\begin{tabular}{|c|c|c|c|c|c|}
\hline Constituent & $\begin{array}{c}\text { Frequency of } \\
\text { detects }\end{array}$ & Minimum & Median & Maximum & MCL \\
\hline \multicolumn{6}{|c|}{ Major elements and water quality parameters } \\
\hline Aluminum & $55 / 55$ & 0.06 & 616 & 1890 & - \\
\hline Ammonium & $34 / 36$ & $<0.1$ & 295 & 1020 & - \\
\hline Boron & $52 / 52$ & 0.6 & 2.2 & 5.1 & - \\
\hline Bromide & $41 / 49$ & 0.1 & 1.5 & 6.4 & - \\
\hline Calcium & $58 / 58$ & 218 & 510 & 960 & - \\
\hline Chloride & $51 / 51$ & 138 & 1450 & 3340 & - \\
\hline Fluoride & $44 / 45$ & $<0.05$ & 28.2 & 58.8 & - \\
\hline Iron & $58 / 58$ & 0.04 & 412 & 1480 & - \\
\hline Magnesium & $58 / 58$ & 9.6 & 270 & 800 & - \\
\hline Manganese & $58 / 58$ & 0.86 & 28.8 & 95.2 & - \\
\hline $\mathrm{pH}$ & $60 / 60$ & 2.39 & 3.13 & 7.17 & - \\
\hline Phosphate & $43 / 43$ & 0.1 & 2.9 & 29 & - \\
\hline Potassium & $58 / 58$ & 5 & 150 & 500 & - \\
\hline Redox potential & $15 / 15$ & 431 & 486 & 606 & - \\
\hline Silica & $44 / 44$ & 43 & 108 & 161 & - \\
\hline Sodium & $58 / 58$ & 236 & 993 & 4090 & - \\
\hline $\begin{array}{l}\text { Specific } \\
\text { conductance }\end{array}$ & $56 / 56$ & 1500 & 11250 & 20600 & - \\
\hline Strontium & $60 / 60$ & 0.44 & 12.5 & 21.8 & \\
\hline Sulfate & $58 / 58$ & 502 & 8240 & 19700 & - \\
\hline $\begin{array}{l}\text { Total dissolved } \\
\text { solids }\end{array}$ & $59 / 59$ & 922 & 12700 & 34200 & - \\
\hline Total organic carbon & $26 / 26$ & 3 & 43 & 141 & - \\
\hline
\end{tabular}

Ref: DOE, 1994b.

Notes:

1. All data in milligrams per liter ( $\mathrm{mg} / \mathrm{L}$ ) except for radium-226, radium-228 and net gross alpha expressed as picocuries per liter $(\mathrm{pCi} / \mathrm{L}), \mathrm{pH}$ expressed in standard units, redox potential expressed as millivolts $(\mathrm{mV})$, and specific conductance expressed as micromohs per centimeter $(\mu \mathrm{moh} / \mathrm{cm})$.

2. Maximum concentration level $(M C L)$ is the maximum concentration limit.

3. Data are compiled from the following lysimeters and monitor wells completed in former tailings piles: Lysimeters FCT03-211, -212, -213, -221, -222, -223, -241, -242, -251, -261, -271, -272, -273, -274; monitor wells FCT03-601, $-602,-607,-940$.

4. $\mathrm{MCL}$ and data for nitrate are expressed as nitrate $\left(\mathrm{NO}_{3}\right)$ rather than nitrogen $(\mathrm{N})$.

5. MCL for uranium is expressed as $\mathrm{mg} / \mathrm{L}$ natural uranium.

6. Dashes (-) indicate that no MCL has been established by the EPA.

7. ND indicates that the parameter was analyzed for, but not detected. 
Table 5.6 Monitored constituents at the Falls City, Texas, disposal site

\begin{tabular}{|c|c|c|c|}
\hline $\begin{array}{l}\text { Hazardous } \\
\text { constituents having } \\
\text { MCLs }\end{array}$ & $\begin{array}{l}\text { Hazardous } \\
\text { constituents without } \\
\text { MCLs }\end{array}$ & Major element parameters & Field parameters \\
\hline $\begin{array}{l}\text { Arsenic } \\
\text { Cadmium } \\
\text { Chromium } \\
\text { Lead } \\
\text { Molybdenum } \\
\text { Nitrate } \\
\text { Selenium } \\
\text { Uranium } \\
\text { Radium-226 } \\
\text { Radium-228 } \\
\text { Net gross alpha }\end{array}$ & $\begin{array}{l}\text { Antimony } \\
\text { Beryllium } \\
\text { Cobalt } \\
\text { Copper } \\
\text { Nickel } \\
\text { Sulfide } \\
\text { Thallium } \\
\text { Tin } \\
\text { Vanadium } \\
\text { Zinc }\end{array}$ & $\begin{array}{l}\text { Aluminum } \\
\text { Ammonium } \\
\text { Bromide } \\
\text { Calcium } \\
\text { Chloride } \\
\text { Iron } \\
\text { Magnesium } \\
\text { Manganese } \\
\text { Potassium } \\
\text { Sodium } \\
\text { Sulfate } \\
\text { Total dissolved solids }\end{array}$ & $\begin{array}{l}\text { Alkalinity } \\
\text { pH } \\
\text { Redox potential } \\
\text { Specific conductance } \\
\text { Temperature }\end{array}$ \\
\hline
\end{tabular}

Notes:

1. Monitored hazardous constituents are inorganic hazardous constituents detected in more than 10 percent of the tailings fluid samples and having maximum observed levels in excess of maximum concentration limits (MCL), if applicable. See Table 5.5. Hazardous constituents which do not meet these criteria are mercury, silver and cyanide.

2. Filtered samples will be collected for analysis.

To monitor ground water at the Falls City site, the DOE proposes to use existing wells in proximity to the disposal cell. Water quality has been established for these existing wells prior to and during surface remediation. However, it is possible that surface remediation activities may have influenced ground water in these wells. For example, placement of the cell may have resulted in compaction within the underlying aquifer. The compaction could cause temporary changes in water levels and ground water flow resulting in transient changes in conditions. Such changes are not related to cell performance, and need to be incorporated as baseline data of initial ambient conditions. For this reason, a minimum of four sample rounds from each monitor well will be collected over a 1-year period to establish conditions in the vicinity of the cell. The monitor wells are all located sufficiently far away from the cell such that any transient drainage from the cell itself should not be observed in monitoring wells until 1997, at the earliest. Thus, ambient conditions will be established prior to 1997 . These ground water samples will be analyzed for identified hazardous constituents, major element parameters, and field parameters listed in Table 5.6.

After the disposal cell is completed, dissipation of excess pore-water may occur. In addition, gravity may drain water added to the cell during construction. Drainage from consolidation of tailings and seepage of construction water are transient conditions that could cause temporary changes in ground water levels and ground water quality near the cell. Such changes, however, are not related to the performance of the disposal cell cover, and any temporary variations in waters levels and quality should be incorporated in the baseline data of initial ambient conditions at the disposal site. 


\section{Indicator parameters}

Indicator parameters will be monitored to determine significant increases (or decreases) over the initial ambient conditions. Changes in concentrations of indicator parameters may signal changes in the existing geochemical conditions that influence contaminant transport. One such geochemical condition that influences contaminant transport is the natural capacity of the Conquista sandstone to neutralize the acidic seepage from tailings (BEG, 1992). For this reason existing ground water within the Conquista sandstone generally has a $\mathrm{pH}$ in the range of 5.4 to 6.6 as compared to a typical value of 3.1 in the tailings pore waters. By contrast, the Deweesville Sandstone has less neutralization capacity and baseline ground water in the Deweesville remains acidic (pH of about 4). Because $\mathrm{pH}$ is a sensitive indicator of changes in geochemical conditions, and because $\mathrm{pH}$ exerts a major control on contaminant transport, $\mathrm{pH}$ is chosen as the indicator parameter to signal changes in these geochemical conditions.

Monitored constituents will include at least the following:

- Field parameters ( $\mathrm{pH}$, electrical conductivity, oxidation-reduction potential, and temperature).

- Alkalinity, ammonium, calcium, chloride, magnesium, potassium, sodium, sulfate, uranium, molybdenum, selenium, aluminum, iron, manganese, and zinc.

The parameter that will be used as indicator of deviation from baseline will be $\mathrm{pH}$. The additional parameters will be collected to provide a data base for evaluation of deviations, should such evaluation be necessary.

\subsection{DATA VALIDATION AND QUALITY ASSURANCE}

The UMTRA Project TAC has established standard operating procedures (SOP) for monitor well installation and development, water and soil sampling, sample preservation and transport, field procedures, chain of custody samples for laboratory analysis, acquisition protocols, and validating and managing analytical data. All aspects of ground water monitoring are conducted in accordance with these procedures, which are updated regularly to reflect changes in industry standards, BMPs, and DOE and EPA guidance. The quality assurance (QA) procedures are consistent with the Resource Conservation and Recovery Act ground water technical enforcement guidance document (EPA, 1986) and the long-term surveillance program QA program plan (DOE, 1992c).

\subsection{REPORTING}

The DOE maintains and updates specific records required to document long-term surveillance program activities at the Falls City UMTRA Project site. The DOE will submit an annual report to the NRC documenting the results of the LTSP, as required by 10 CFR $\$ 40.27$ (1995). DOE will keep all relevant and required records at an appropriate location. These documents will be available for review by the NRC and the public. 


\subsection{SITE INSPECTIONS}

Inspections of the Falls City disposal site will be documented in an inspection report to record any changes to the disposal cell and site over time and to identify potential problems before the need for extensive maintenance, repairs, or corrective action. Fundamental to the inspections will be the detection and documentation of progressive change caused by slow-acting natural processes. The findings from these inspections will be compared to the initial baseline conditions to provide a basis for future inspections. The three types of site inspections are as follows:

- Annual or scheduled site inspections.

- Follow-up inspections.

- Contingency inspections.

Each site inspection must be documented in a report that identifies the findings of the inspection. Copies of the report will be submitted to the NRC and the state of Texas and will be placed in the Falls City permanent site file. Annual or scheduled site inspection reports will be completed and submitted to the NRC within 90 days of the last UMTRA Project site inspection of that calendar year. Follow-up or contingency inspection reports must be submitted to the NRC within 60 days of the initial report and within 60 days after any other type of inspection.

\section{$6.1 \quad$ INSPECTION FREQUENCY}

The Falls City disposal site will be inspected annually for the first 5 years after licensing. At the end of the 5-year period, the GJPO will evaluate the need to continue annual inspections, basing its recommendation on an evaluation of the annual reports and any other reports filed for maintenance or unscheduled events. If it is determined that less frequent inspections are required, the GJPO will modify the LTSP and submit it to the NRC for approval. The state of Texas will also receive copies for review. Subsequent inspections will be considered a scheduled site inspection.

\subsection{INSPECTION TEAM}

The inspection team will consist of a chief inspector and one or more assistants. The chief inspector will be a geotechnical engineer, a civil engineer, or an engineering geologist knowledgeable in processes that could adversely affect the site (e.g., geomorphic agents of change).

When they are needed for follow-up or assessment inspections, the team will include additional technical experts appropriate to the problems under investigation. 


\section{PREPARATION FOR INSPECTION}

Before each inspection, inspectors will complete the following tasks:

- Review the final LTSP, the permanent site file, the previous site inspection report(s) and site inspection map(s), and all maintenance or corrective action reports.

- Prepare the site inspection checklist based on previous inspections or repairs; incorporate any needed modifications.

- Verify and update the names and telephone numbers of all parties with whom access or notification agreements have been executed.

- Verify the DOE 24-hour telephone number and appropriate agency telephone numbers and contacts; arrange to modify the entrance sign, as needed.

- Schedule the site inspection.

- Assemble all equipment needed for the inspection.

- Adjust the Brunton compass's magnetic declination for that of the Falls City area (currently approximately 9.5 degrees east of north).

- Notify the NRC, the state of Texas, and adjacent land owners for their possible attendance at the inspection. Names and addresses of adjacent land owners are provided in the Falls City permanent site file at the GJPO.

\subsection{SITE INSPECTION AND INSPECTION CHECKLIST}

The site inspection will cover the disposal site area, the disposal cell, and the immediate off-site areas. All site inspection activities and observations should be recorded and described using the as-builts, initial site inspection checklist (Attachment 4), site inspection map, a field notebook, and photographs. Observations and photographic stations should be recorded on the field maps. After the inspection is complete, these maps should be drafted and kept in the permanent site file.

The initial site inspection checklist is a guideline for the inspectors. After each inspection is complete, the checklist will be revised to include new information or to delete items that are no longer pertinent. Revisions to the checklist will be documented in the inspection report.

A photographic record of the site inspection must be maintained. Site conditions should be documented by ground photographs to record developing trends and to enable the DOE to evaluate the need for and extent of future activities. If possible, any site feature or condition requiring inspectors to make a written comment, explanation, or description will be photographed. A site inspection photo log will be used to record the photographs (Attachment 3). All features will be photographed and recorded as 
specified in Section 3.5. The inspectors may determine the number of photographs, the view angles, and the lenses used to ensure that sufficient photographs are taken for agency review.

\subsubsection{Off-site areas}

The area within a maximum of $0.25 \mathrm{mi}(0.40 \mathrm{~km})$ from the center of the disposal site will be surveyed for evidence of land-use changes that indicate increased human activity (i.e., greater probability of intrusion onto the site). New roads or paths, changes in vegetation, and relevant geomorphic features like gullies or aeolian formations, any of which could initiate site-threatening erosion, will also be observed.

\subsubsection{On-site areas}

The integrity of the disposal cell will be evaluated from a series of transects walked around the perimeter; along the base, crest, and sideslopes; and in and around the apron. Sufficient transects must be walked so that the disposal cell is thoroughly covered and inspected. Diagonal transects of the crest will be made, and the edge of the crest will be walked. Additional transects, at approximately 50-yd (46-m) intervals, will be walked along the sideslopes. Transects along the entire length of each diversion channel will be made to determine whether the channels have been functioning and can be expected to continue to function as designed.

At minimum, the site perimeter and site area transects will be monitored for damage to or disturbance of the following features:

- Fences, gates, and locks.

- Permanent site-surveillance features.

- Ground water monitor wells.

- Site area vegetation or volunteer plant growth.

- Sedimentation or erosion.

The complete length of transects along the engineered component (diversion channels and disposal cell sideslopes, and crest) will be walked and examined for evidence of the following:

- Structural instability resulting from differential settlement, subsidence, cracking, sliding, or creep.

- Erosion as evidenced by developing rills or gullies.

- Sedimentation or debris.

- Rapid rock cover deterioration caused by weathering or erosion.

- Removal of rock or other disposal cell material.

- Seepage. 
- Intrusion (inadvertent or deliberate) by humans or animals.

- Animal burrowing.

- Vandalism.

- Trails showing human or animal activity.

- Volunteer plant growth.

\section{MODIFYING PROCESSES}

Modifications from natural processes will most likely be on the topslopes and the lower portions of the sideslopes of the disposal cell and in and around the apron. Plant and animal intrusion can also cause modifications to engineered components of the disposal cell. The inspection report will detail any observed modifying features, and will include a description of the problem, relevant measurements and photographs, and an assessment of possible impacts. The description of the modifying process will include information such as the following:

- Extent of area affected.

- Number, spacing, length, depth, and width of features (e.g., gullies).

- Patterns of occurrence.

- Species present, if plant or animals are found at the site.

- Location and density of volunteer plant growth.

Inadvertent or casual intrusion by humans or animals is not of great concern, but evidence of cover removal, extensive vandalism to signs and monuments, or the presence of well-established trails will be described in detail. Continued vandalism may require more active measures to control site access.

If new conditions requiring monitoring or immediate action are discovered during the inspection, the inspection report should include a description of the problem and the recommended follow-up action (if required).

\subsection{VEGETATION}

\subsubsection{Planned vegetation}

The top of the disposal cell is a vegetative cover. A 6-inch (152-mm) layer of topsoil was placed on top of the 3-foot (0.9-m)-thick growth medium material. 
The soil was fertilized with a standard commercial grade fertilizer consisting of 77 percent nitrogen and 23 percent phosphate. The amount placed was an average of 262 pounds per acre (lb/ac) (293 kilograms/hectare [kg/ha]).

Prior to seed application, the top of the disposal cell was disced and raked to ensure that 6 inches $(152 \mathrm{~mm}$ ) of topsoil was in a loose, friable condition pursuant to seeding specifications. All seeding was accomplished with a range land drill set at 0.5 inches $(13 \mathrm{~mm})$ to 0.75 inches $(19 \mathrm{~mm})$, per specifications.

The topslope was planted with the following seed ratio and poundage:

$\begin{array}{lll}\text { Green Sprangletop } & \begin{array}{l}165.0 \mathrm{lbs} \\ (71.9 \mathrm{~kg})\end{array} & \begin{array}{l}1.90 \mathrm{lb} / \mathrm{acre} \\ (2.12 \mathrm{~kg} / \mathrm{ha})\end{array} \\ \text { Common Bermuda } & \begin{array}{l}888.0 \mathrm{lbs} \\ (402.8 \mathrm{~kg})\end{array} & \begin{array}{l}10.20 \mathrm{lb} / \mathrm{acre} \\ (11.40 \mathrm{~kg} / \mathrm{ha})\end{array} \\ & \begin{array}{l}74.7 \mathrm{lbs} \\ (33.9 \mathrm{~kg})\end{array} & \begin{array}{l}0.96 \mathrm{lb} / \mathrm{acre} \\ (1.1 \mathrm{~kg} / \mathrm{ha})\end{array} \\ \text { Sideoats Grama } & 447.0 \mathrm{lbs} & 5.14 \mathrm{lb} / \mathrm{acre} \\ & (202.8 \mathrm{~kg}) & (5.74 \mathrm{~kg} / \mathrm{ha}) \\ \text { Kleingrass } & & 18.20 \mathrm{lb} / \mathrm{acre} \\ & & (20 \mathrm{~kg} / \mathrm{ha})\end{array}$

After completion of the disposal cell, a plant specialist or other qualified person will periodically participate in site inspections. If the inspection does not coincide with the general growing season, the plant specialist may conduct a separate inspection at a more favorable time. Conditions such as drought may cause the vegetative cover to die. This may require reseeding, which should be coordinated with the local U.S. Soil Conservation Service agent.

To prevent excessive growth in the vegetative cover, mowing operations will be conducted annually, semiannually in late spring (May-June), and early fall (September - October), on top and around the disposal cell within the permanent withdrawal area.

\subsubsection{Volunteer plant growth}

Volunteer plant growth includes plants growing where none were planned, such as in rock-lined drainage ditches, or unwanted plant species growing on the vegetated topslope of the disposal cell.

A follow-up inspection by a plant specialist may be required if an inspection team reports woody plant species such as mesquite growing on the vegetative cover. It is anticipated that the growth of woody species on the vegetative cover will be minimized after the grass cover has become established. Woody plants and other unwanted plant species will be eliminated from the cover. This elimination may involve selective spraying or mechanical removal on an annual basis. 
A new site inspection map will be prepared after each scheduled inspection using the disposal site map (Plate 2) as a base. This map must include the following:

- Inspection traverses.

- Photographic locations.

- Locations and descriptions of any new, anomalous, or unexpected features.

- Features identified during previous inspections for observation or monitoring.

- Inspection date.

\subsection{REPORTING REQUIREMENTS}

Upon completion of the field inspection, Section D of the initial site inspection checklist (Attachment 4) must be completed and the certification statement must be signed. Overlays for the as-built drawings or revised drawings will be developed, noting any potential problems or other site conditions requiring attention. The revised drawings will be labeled with the date and type of site inspection.

All photographs must be logged on a site inspection photo log (Attachment 3). A separate photo log should be completed for each roll of exposed film, with an entry for each photograph. The completed photo logs should be attached to the inspection checklist and paginated accordingly.

Documentary evidence of anomalous, new, or unexpected conditions or situations must be included to record developing trends and to enable the responsible agency to make reasonable decisions concerning follow-up inspections, custodial maintenance, and/or repair, and corrective action. Photographs may be considered to be documentation.

A site inspection report including the following information will be completed after every routine site inspection:

- Narrative of site inspection, including results, conclusions, and recommendations.

- Site inspection checklists and all relevant supporting documentation.

- Site inspection map and other drawings, maps, or figures, as required.

- Inspection photographs and photo log sheet.

- Recommendations for additional follow-up inspections, or custodial maintenance and/or repair, if required. 
- Follow-up or contingency inspection reports, if required.

- Custodial maintenance and/or repair report and certification, if required.

- Inspection certification.

- Ground water monitoring data and analyses, if applicable.

Appendix A, Criterion 12 of 10 CFR Part 40 requires the DOE to submit results of all routine site inspections to the NRC and the state of Texas within 90 days of the last UMTRA Project site inspection for that calendar year. A copy of all site inspection reports will be maintained in the permanent site file and a copy of the inspection report will also be sent to the state of Texas. 


\subsection{REFERENCES}

ASP (American Society of Photogrammetry), 1980. Manual of Photogrammetry, fourth edition, American Society of Photogrammetry, Falls Church, Virginia.

BEG (Bureau of Economic Geology), 1992. Hydrogeology and Hydrochemistry of the Falls City Uranium Mine Tailings Remedial Action Project, Karnes County, Texas, Cooperative Agreement No. IAC (92-93)-0389, prepared for the Texas Department of Health, Bureau of Radiation Control, Austin, Texas.

DOE (U.S. Department of Energy), 1995. Site Observational Work Plan for the UMTRA Project Site at Falls City, Texas, May 1995, DOE/AL/62350-157, Rev. O, DOE UMTRA Project, DOE Environmental Restoration Division, Albuquerque, New Mexico.

DOE (U.S. Department of Energy), 1994a. Uranium Mill Tailings Remedial Action Project 1993 Environmental Report, October 1994, DOE/AL/62350-101, DOE UMTRA Project, DOE Environmental Restoration Division, Albuquerque, New Mexico.

DOE (U.S. Department of Energy), 1994b. Baseline Risk Assessment of Ground Water Contamination at the Uranium Mill Tailings Site Near Falls City, Texas, September 1994, DOE/AL/62350-64, Rev. 1, DOE UMTRA Project, DOE Environmental Restoration Division, Albuquerque, New Mexico.

DOE (U.S. Department of Energy), 1993. Licensing Plan for UMTRA Project Disposal Sites, final, September 1993, DOE/AL/62350-9F, DOE UMTRA Project, DOE Environmental Restoration Division, Albuquerque, New Mexico.

DOE (U.S. Department of Energy), 1992a. Guidance for Implementing the UMTRA Project LongTerm Surveillance Program, final, September 1992, UMTRA-DOE/AL-350125.0000, DOE UMTRA Project, DOE Environmental Restoration Division, Albuquerque, New Mexico.

DOE (U.S. Department of Energy), 1992b. Remedial Action Plan and Site Design for Stabilization of the Inactive Uranium Mill Tailings Site at Falls City, Texas, September 1992, 050520.0000, DOE UMTRA Project, DOE Environmental Restoration Division, Albuquerque, New Mexico.

DOE (U.S. Department of Energy), 1992c. Long-Term Surveillance and Maintenance Program Quality Assurance Program Plan, P-GJPO-152, July 1992, prepared for the U.S. Department of Energy by Chem Nuclear Geotech, Inc., DOE Grand Junction Projects Office, Grand Junction, Colorado.

DOE (U.S. Department of Energy), 1991. Environmental Assessment of Remedial Action at the Falls City Uranium Mill Tailings Site, Falls City, Texas, December 1991, DOE/EA-0468, DOE UMTRA Project, DOE Environmental Restoration Division, Albuquerque, New Mexico. 
DOE (U.S. Department of Energy), 1989. Cooperative Agreement Between the United States Department of Energy and State of Texas, DOE Cooperative Agreement No. DEFC04-87AL20532, DOE UMTRA Project, DOE Environmental Restoration Division, Albuquerque, New Mexico.

EPA (U.S. Environmental Protection Agency), 1986. RCRA Ground Water Monitoring Technical Enforcement Guidance Document, OSWER Directive 9950.1.

JEG (Jacobs Engineering Group, Inc.), n. d., Albuquerque Operations Manual, Standard Operating Procedures, prepared by Jacobs Engineering Group, Albuquerque, New Mexico, for the DOE UMTRA Project, DOE Environmental Restoration Division, Albuquerque, New Mexico.

MKF (MK-Ferguson), 1995. Falls City, Texas, Draft Completion Report, March 1995, Contract No. DE-AC04-83AL18796, prepared by MKF for the DOE UMTRA Project, DOE Environmental Restoration Division, Albuquerque, New Mexico.

MK (Morrison-Knudsen), 1993. Long-Term Surveillance Plan Subcontract Documents - Final Design for Review, July 1993, prepared by MK for the DOE UMTRA Project, DOE Environmental Restoration Division, Albuquerque, New Mexico.

\section{DOE ORDERS}

Order 1324.2A, Records Disposition, September 13, 1988, Office of Information Resources Management, U.S. Department of Energy, Washington, D.C.

Order 5000.3B, Occurrence Reporting and Processing of Operations Information, February 22, 1993, U.S. Department of Energy, Washington, D.C.

Order 5400.1, General Environmental Protection Program, June 29, 1990, U.S. Department of Energy, Environmental Protection Division, Office of Environment, Safety and Health, Washington, D.C.

Order 5480.1B, Environment, Safety and Health (ES\&H) Program for DOE Operations, September 1986, U.S. Department of Energy, Safety Programs Division, Washington, D.C.

Order 5700.6C, Quality Assurance, August 21, 1991, Office of Nuclear Energy and Office of Environment, Safety, and Health, U.S. Department of Energy, Washington, D.C.

\section{FEDERAL REGISTER}

60 FR 2854-2871, Groundwater Standards for Remedial Actions at Inactive Uranium Processing Sites, January 11, 1995.

55 FR 45591, Custody and Long-Term Care of Uranium and Thorium Mill Tailings Disposal Sites, October 30, 1990. 


\section{U.S. CODE}

42 USC $§ 7901$ et seq., Uranium Mill Tailings Radiation Control Act of 1978, November 8, 1978.

\section{CODE OF FEDERAL REGULATIONS}

10 CFR Part 40, Domestic Licensing of Source Material, U.S. Nuclear Regulatory Commission.

36 CFR Parts 1220-1238, National Archives and Records, Subchapter B - Records Management, National Archives and Records Administration.

40 CFR Part 192, Health and Environmental Protection Standards for Uranium and Thorium Mill Tailings, U.S. Environmental Protection Agency.

40 CFR Part 264, Standards for Owners and Operators of Hazardous Waste Treatment, Storage, and Disposal Facilities, U.S. Environmental Protection Agency.

41 CFR Part 101, Federal Property Management Regulations, General Services Administration. 